\title{
DEMOGRAPHIC RESULTS IN RUSSIA, 2013: SUMMARY REPORT *
}

\author{
INSTITUTE OF DEMOGRAPHY, HIGHER SCHOOL OF ECONOMICS
}

\begin{abstract}
The Institute of Demography of the HSE annually prepares a detailed research report on the demographic development of the country in the previous year. However, due to the fact that work on the full report and its publication take a fairly long time, in this issue we publish a short, express version of the report, which gives an indication of the main results of the demographic development of Russia in 2013.
\end{abstract}

Keywords: Russia, demographic results, population, age composition, fertility, mortality, internal migration, international migration.

\section{THE SIZE AND AGE COMPOSITION OF THE POPULATION}

In 2013, Russia's positive demographic trends of the last few years mostly continued. The major success of this year was the appearance, for the first time since 1991, of a positive natural population increase (of 24 thousand people). The total increase of the population, taking into account migration, was 319,800 . As a result, by the beginning of 2014 the population of Russia had reached 143.7 million people, surpassing the minimum population of the year 2009 by 1763 thousand people. At the same time, it is still below the maximum population of 1993 by 4.9 million. ${ }^{1}$

The main source of growth of the Russian population is the influx of migrants, which has made a positive contribution since the mid-1970s (before which Russia's migration balance was negative), but then, as a rule, provided no more than a quarter of the total increase. Since 1992, in conditions of a natural population decrease, immigration has been the only source of population growth, but usually insufficient to compensate for the natural decrease (Figure 1). In 21 years of natural population decline in Russia (1992-2012), it amounted to 13.2 million people. The total size of the migration increase over the same period was 8.4 million, which compensated $63 \%$ of the natural decrease of population during this period.

The reduction in the natural decrease of Russia's population observed in recent years is a positive phenomenon, but apparently a temporary one as well, due to transitory factors that are almost impossible to influence.

\section{INSTITUTE OF DEMOGRAPHY, NATIONAL RESEARCH UNIVERSITY HIGHER SCHOOL OF ECONOMICS. RUSSIA. E-MAIL: mmezhevova@hse.ru}

TRANSLATED FROM: ДЕМОГРАФИЧЕСКОЕ ОБОЗРЕНИЕ. 2014, 1(3): 5-32. ORIGINAL TITLE: "HACEЛЕНИЕ РОССИИ: ДЕМОГРАФИЧЕСКИЕ ИТОГИ 2013 ГОДА. КРАТКИЙ ДОКЛАД” (НТТР://DEMREVIEW.HSE.RU/EN/2014-3/143746230.HTML).

* THE STUdy WAS IMPLEMENTED UNDER THE BASIC RESEARCH PROGRAM AT THE NATIONAL RESEARCH UNIVERSITY, HiGHER SCHOOL OF ECONOMICS (HSE) IN 2014.

\footnotetext{
${ }^{1}$ Unless otherwise noted, this indicates the data in the article is from Rosstat.
} 


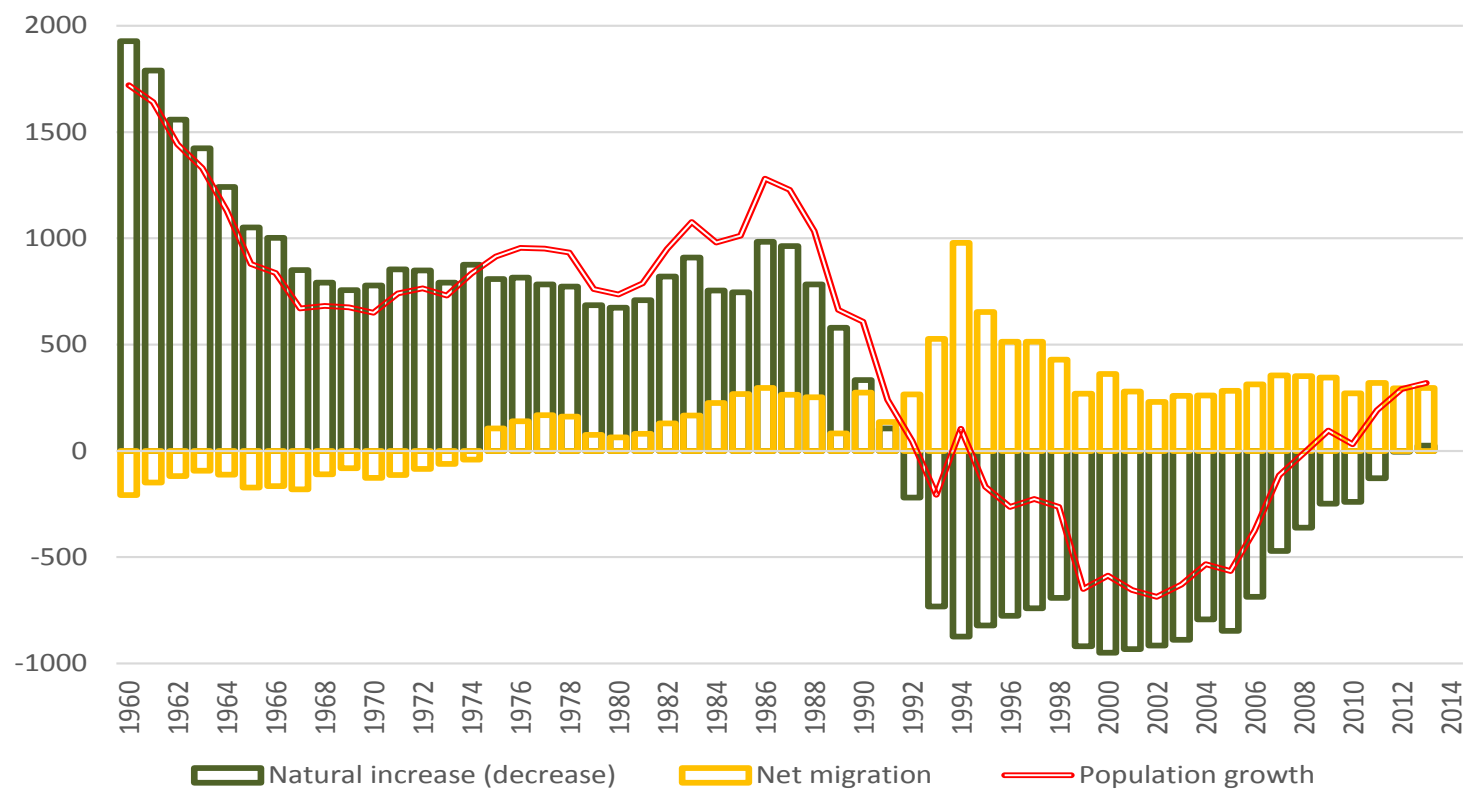

Figure 1. Components of population growth in Russia, 1960-2013

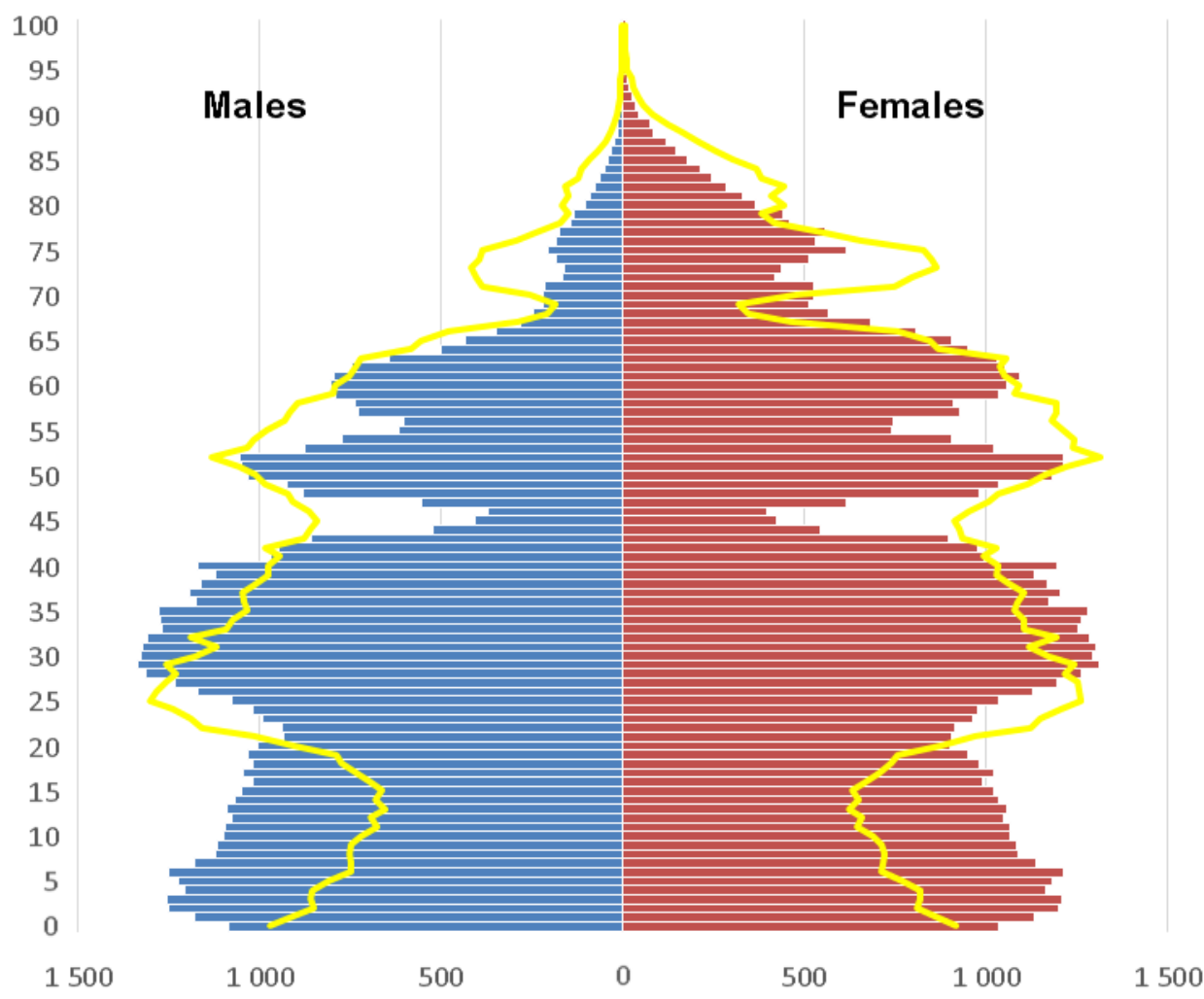

Figure 2. Age pyramid of the population of Russia in 1990 (bars) and in 2013 (solid line), thousands

Chief among them is the existing age composition of the population. The general vector of its change has set in motion an irreversible process of population aging, but is also subject to wavelike fluctuations resulting from the historical upheavals of the past. The comparison in Fig. 2 of the age pyramids in 2013 and 1990 gives an idea of the total transformation of the population's age structure between these two dates. 
In 1990-2013, the wavelike changes in the age composition had an appreciable effect on the ratios of age groups, which had noticeable economic and demographic consequences. In the early 1990s, these consequences were favorable. In particular, Russia entered a phase of receiving a so-called "demographic dividend" which was quite beneficial for the economy.

At this stage, Russia reached its historical maximum of the number of people of working age (20-64) and of their share in the total population (Fig. 3). A particularly large increase (5.1 million people) occurred between 2005 and 2011, 4.2 million of whom were added in 2007-2010, when the large cohorts born between 1987 and 1990 crossed the threshold of 20 years of age while the small cohorts born between 1942 and 1945 retired at age 65 and left working age.

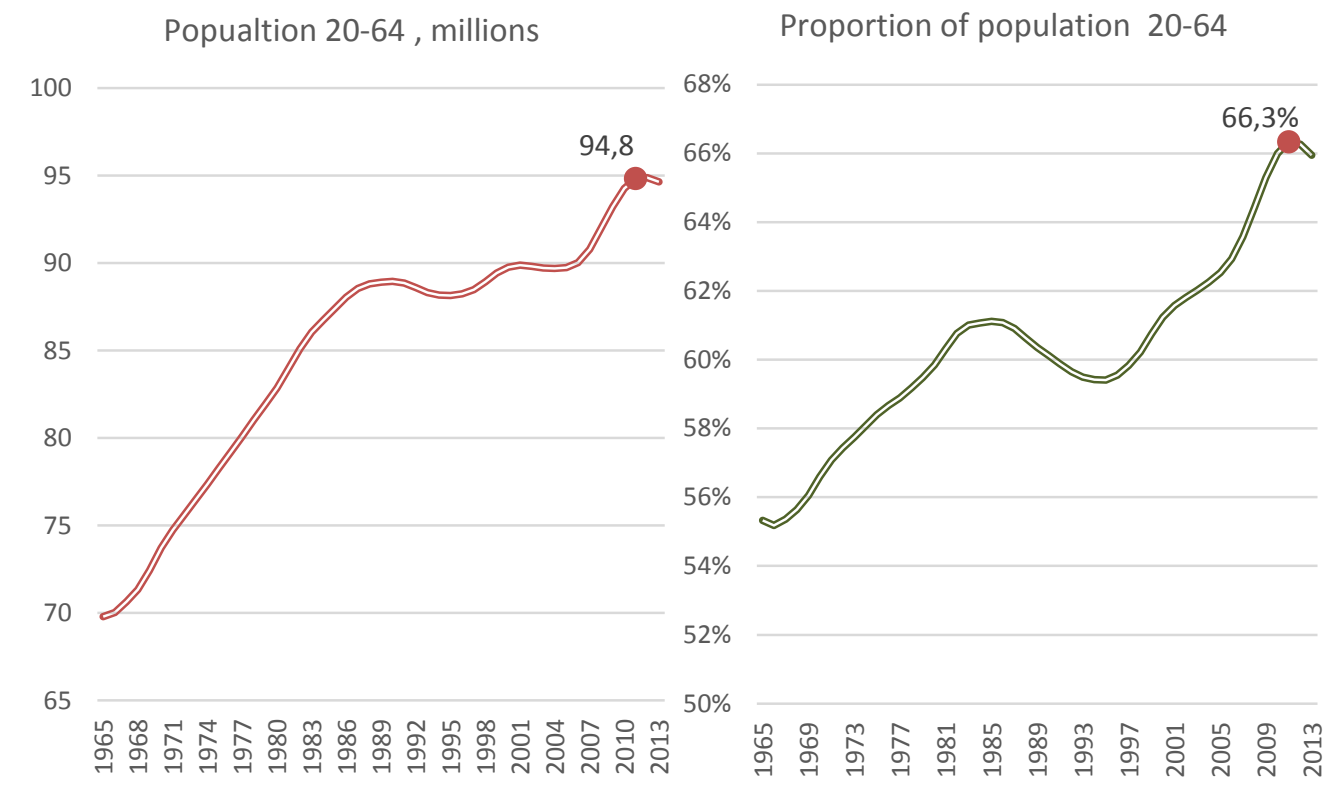

Figure 3. Size and percentage of the population of working age (20-64 years), 1965 - 2013

As follows from Fig. 4, despite some fluctuations, on the whole Russia lived in conditions of a declining total dependency ratio. The elderly dependency ratio gradually increased, but this increase was offset, sometimes more than offset, by a reduction in the youth dependency ratio. In 2011, the total dependency ratio reached a record low, and then began to rise.

This indicated that the era of reduction in the dependency ratio had ended, that Russia had entered a period of rapid growth of both the elderly and the youth dependency ratios. All the projections predict such a growth, and a significant one at that. By the mid-2010s the dependency ratio will return to the level of the early 1990s and will continue to rise, inevitably leading to an increase in unmet demand in the labor market and, consequently, an increase in the demand for labor migrants.

At the same time, it is necessary to pay attention to a seemingly paradoxical, but crucial fact for policy: the more favorable the demographic indicators - that is, the more children are born and the lower the mortality of the adult and elderly population - the faster the dependency ratio will grow. 


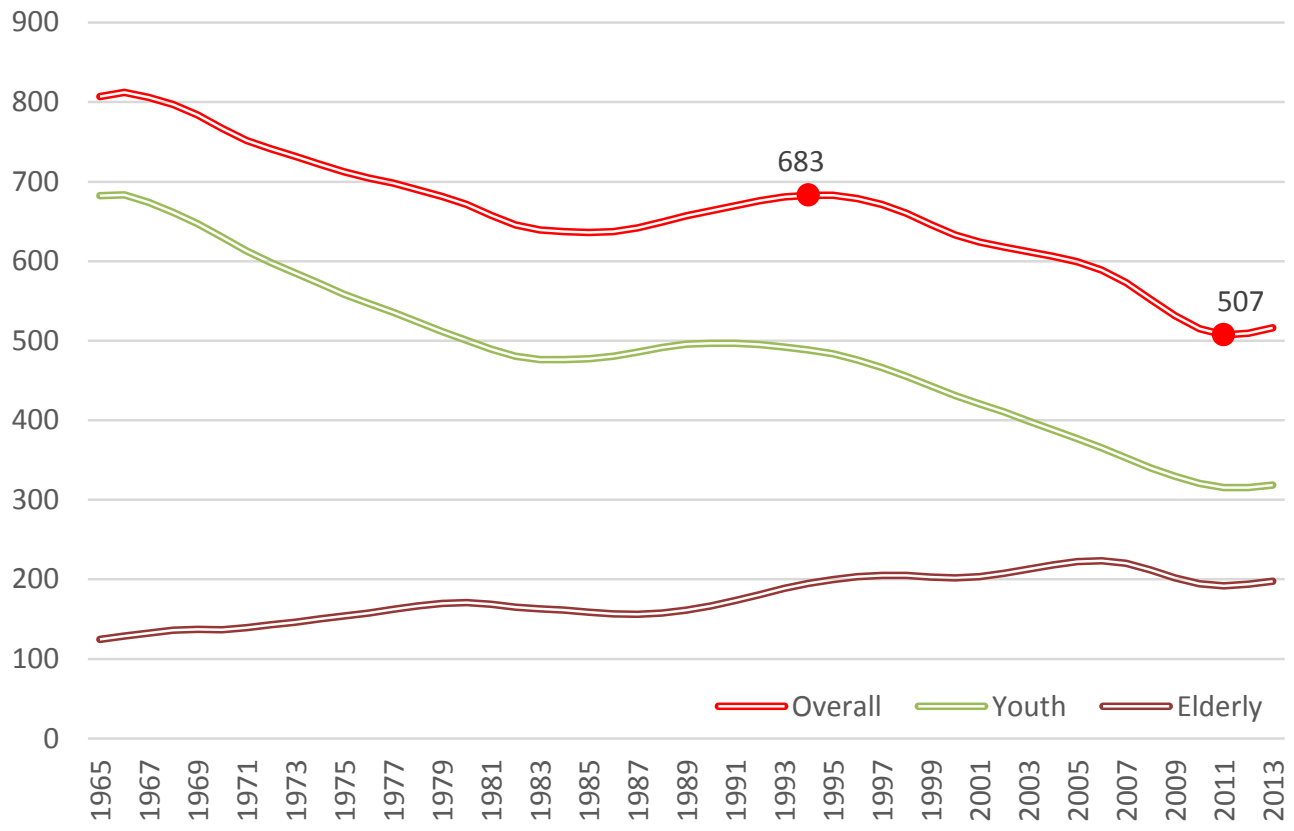

Figure 4. Youth and elderly dependency ratios per 1000 persons aged 20-64

Despite the importance of the economic impact of changes in the age structure of the population of Russia, perhaps even more important is the influence they have on demographic processes.

\section{FERTILITY}

One of these processes is fertility. Changes in the age structure have had and continue to have a very strong but ambiguous impact on the dynamics of fertility in the country. In the 1990s, the number of women of reproductive age (15-49 years) was increasing. In 2003 it reached a historic high, exceeding 40 million ( $27 \%$ of the total population). It should have boosted the number of births, but in reality the number of births decreased to a historic low in 1999 (Fig. 5).

Such a discrepancy in trends seems paradoxical if one does not take into account the differing population dynamics of age groups of women in the broad category 15-49. The overall increase in the number of women of reproductive age in the 1990s was provided by the age groups 15-19, 20-24, but especially by the two older groups (40-44 and 45-49) who have little impact on fertility levels. At the same time, the number of women aged 25-29 in the first half of the 1990s decreased, and that of those aged 30-34 decreased throughout the 1990s (Fig. 7, left panel). 


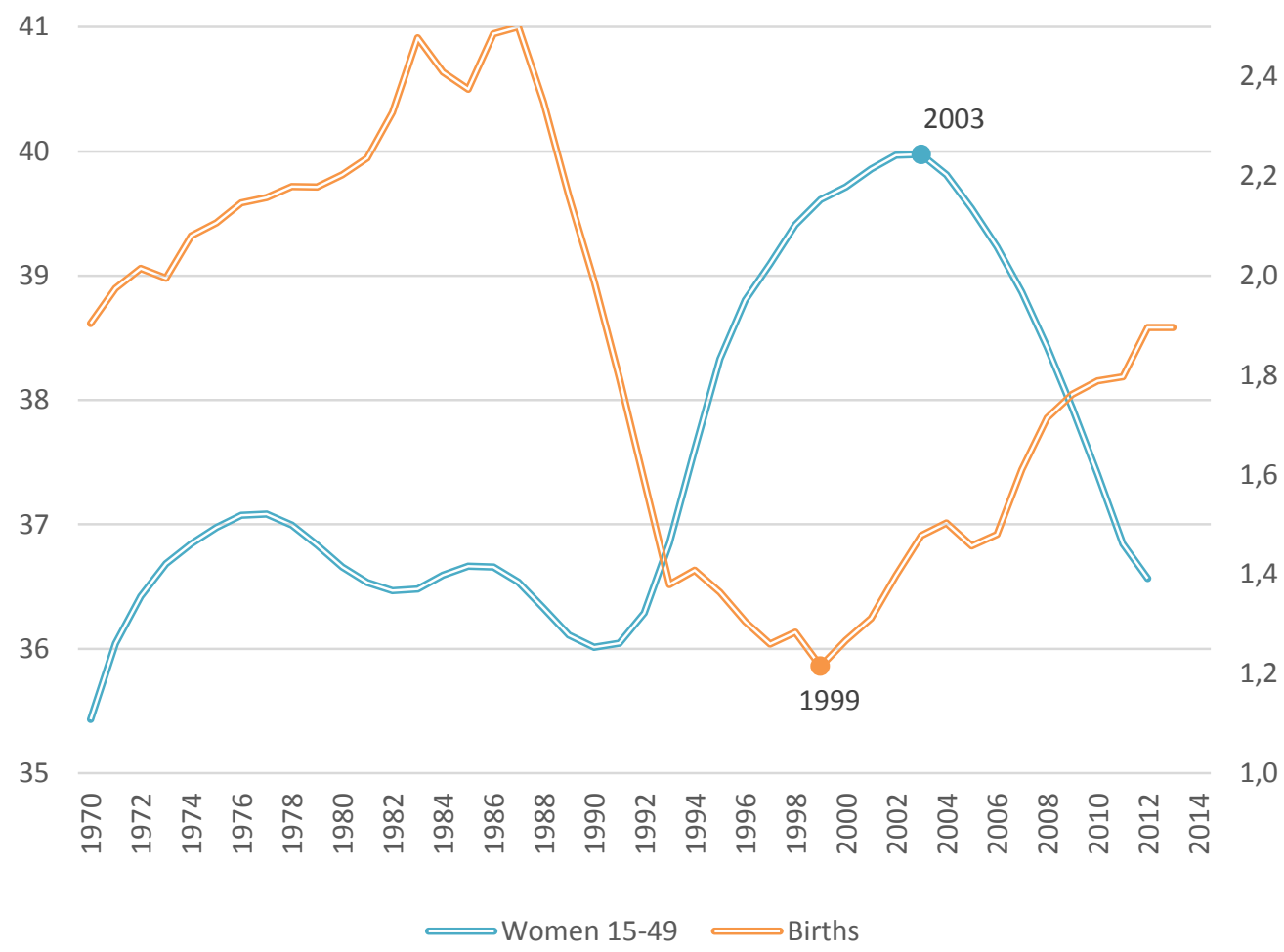

Figure 5. Number of women of reproductive age (left scale) and the number of births (right scale), millions

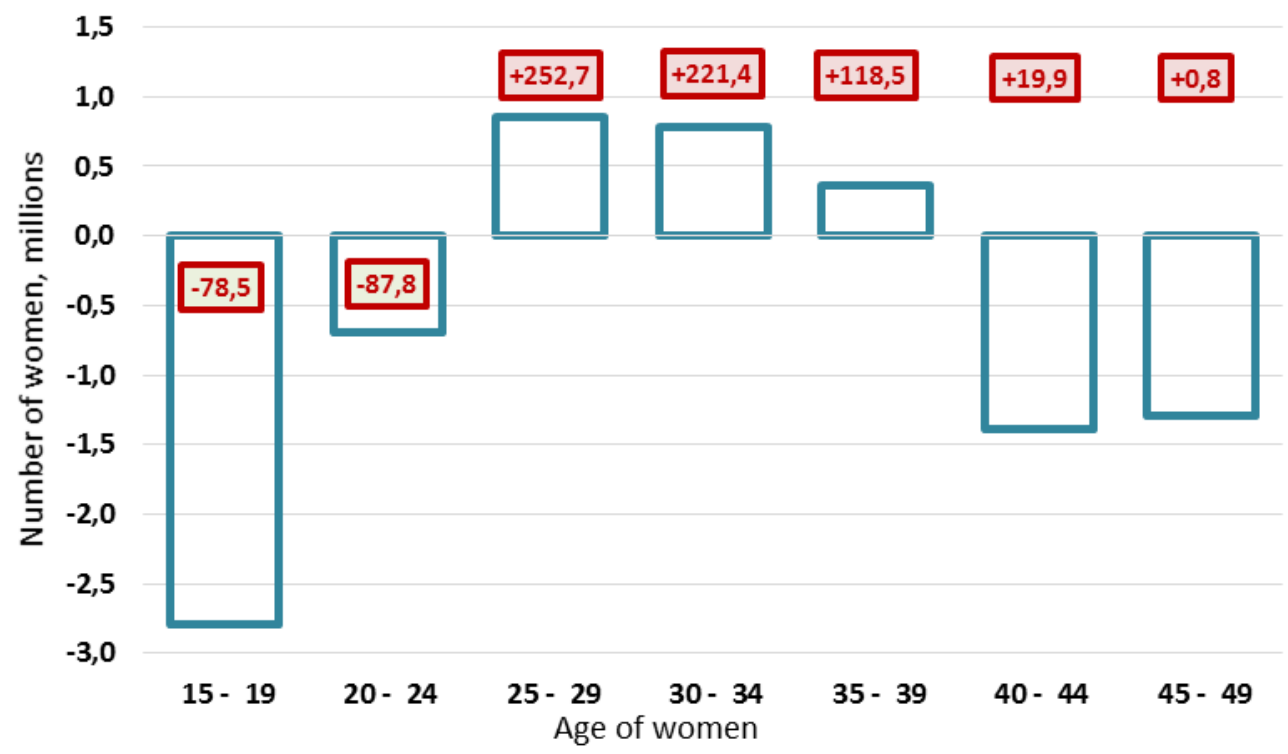

Figure 6. The increase or decline in the number of women in millions (blue columns), and the number of births in thousands (red-framed figures), by age of women, 2004-2013

But in the 2000s the situation changed. With the overall reduction in the number of women aged 15-49 (which since 2004 has already dropped by more than 4 million), the number of women in most important maternal ages increased and keeps growing. Starting from 2000, over $85 \%$ of all births, and since 2009 more than $90 \%$ of all births, have been accounted for by four age groups of women (20-24, 25-29, 30-34 and 35-39). Among them, only the number of 20-24-year-olds fell 
and their number of births fell correspondingly. The increase in the number of births in 2004-2013 was provided mainly by those age groups in which the number of women continued to grow (Fig. 6). The number of women aged 25-29 (born in 1971-1987) increased in the years 2000-2012 by about 1 million (women born from 1971 to 1987), and the number of 30-34-year-olds (born from 1966 to 1982 ) increased by about 850 thousand.

Both the increase and the decrease of the number of births were not proportional to the increase and the decrease of the number of women, since there was at the same time a change in the intensity of fertility at different ages. This is explained by the long-term rapid changes in the age pattern of fertility. It has been "getting older", which corresponds to a global trend that emerged in the 1970s, although Russia was somewhat slow in joining the trend. In Russia women aged 20-24 had the highest fertility for a long time. But in the 1990s, when the number of women of this age increased, their fertility decreased rapidly. On the other hand, from the mid-1990s began a steady increase in fertility of women 30-34 years old, followed since the 2000s by fertility rise among women aged 25-29. Fertility of the age group 25-29 exceeded fertility of the 20-24 age group for the first time in 2008, and the gap between them began to widen. It is hard to link this dynamic to measures of demographic policy. On the right panel of Fig. 7 it can be seen that the increase in the birth rate in the 2000s was observed only in women aged 25-29, 30-34 and, to a lesser degree, 35-39, but this growth began long before the introduction of measures in 2007 . The curve of the total fertility rate (TFR) simply repeats the curve paths of the three age groups.
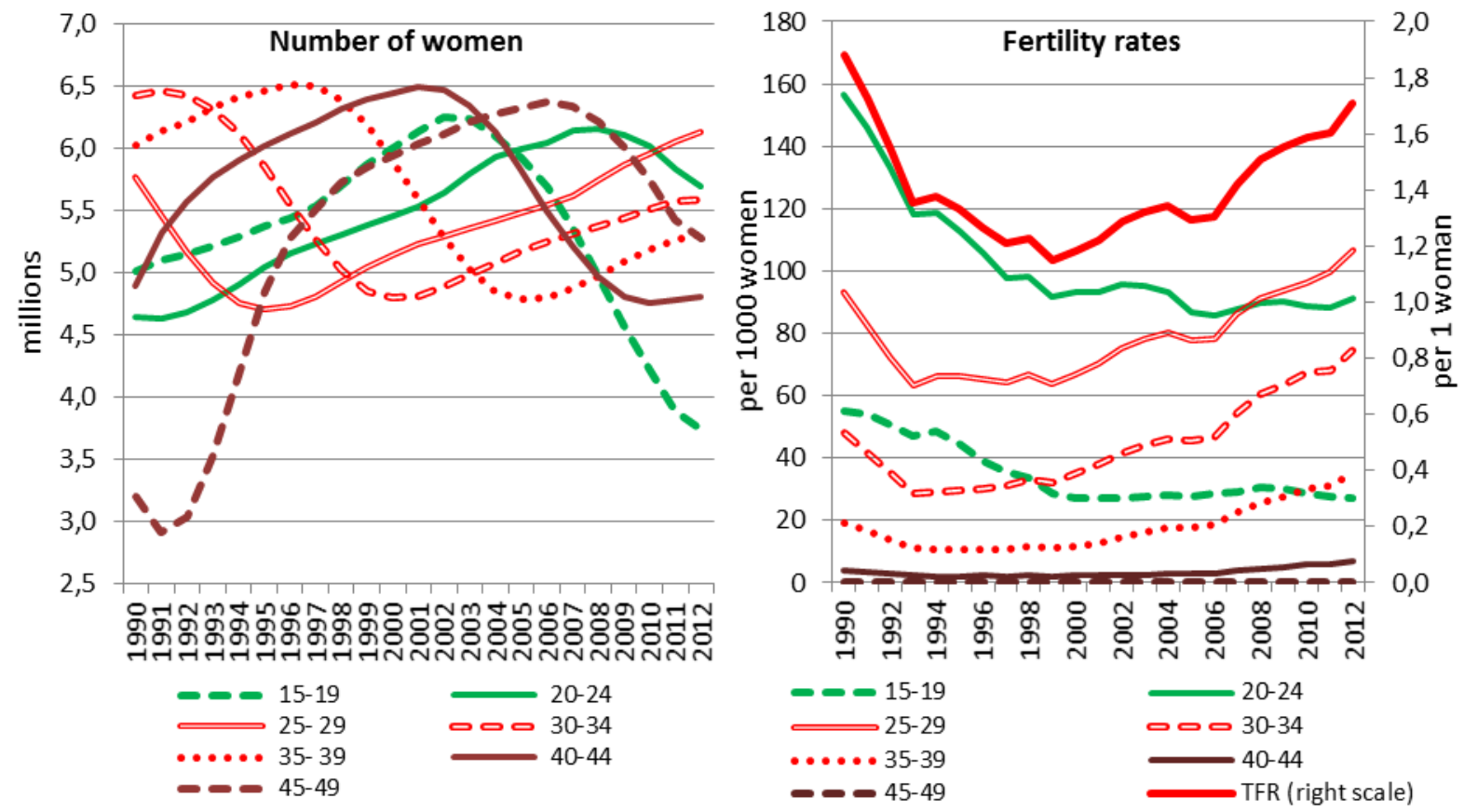

Figure 7. Number of women, age-specific fertility rates by five-year age groups and total fertility rate

The dual increase in the number of potential mothers aged 25 and older and the intensity of fertility at these ages fueled the growth of the number of births from 2000 to 2013 . This growth was achieved mainly by women aged 25 years and older, while the contribution of younger women to the change in the total number of births during this period was negative. Compared with 2000, the number of births in 2013 increased by 629 thousand. That, coupled with a decrease in the 
number of deaths by 353.5 thousand, made it possible to overcome the natural decline of the population in 2013 (in 2000 it was largest at 958.5 thousand).

But now the growth of female age groups with increasing fertility has come to an end. The number of women in the key group of ages 25-29 reached its maximum in 2012, after which it started to decline. Already by 2017 it will decrease by more than 1 million and will become smaller than it has been in 2000. For the 30-34-year-olds the turning point will come in 2018. Maintaining the current number of births with such a reduction in the number of potential mothers will be hardly possible.

As for fertility level proper - i.e. not the number of births in a given calendar year, which depends on a complex and changeable combination of the number of women of different ages and changes in the age profile of fertility, but the final number of births per woman over her lifetime (completed cohort fertility) - there has been little change. Starting with the cohorts born in the second half of the 1960s, this number has fluctuated around the value of 1.6. For younger cohorts, the expected value is slightly higher, close to 1.7 children per woman. An increase of completed fertility of the order of 0.07 per woman between the cohorts born in 1975-1979 and those born in 1985-1989 is the most optimistic scenario, under the assumption that current age-specific fertility rates do not change.

It should also be kept in mind that, despite the government's active policy-making to increase the birth rate, childlessness in Russia is growing. In 1970-1980, no more than 7\% of women aged 50 had no experience of motherhood. By the early 1990s, this figure grew to $10 \%$. According to the latest estimates based on special fertility probability tables, we can expect that, at the current level of fertility, $16 \%$ of women will remain permanently childless. Less than half of the prevalence of childlessness is due to biological and medical impediments (female and male infertility). Substituting abortions with modern, safe contraceptives, a process which has arisen in Russia since the end of the $1980 \mathrm{~s}$, as well as various auxiliary reproductive technologies, which have also become more and more widespread, limits childlessness somewhat, but does not eliminate it.

Of greater importance is the creation of equal conditions for childbearing in all types of partnerships, be they officially registered marriages or informal (consensual) unions. In the last quarter of the 20th century, official marriages in Russia have not only begun taking place significantly later (the average age of marriage has risen by more than three years), but have lost the dominant position as the initial form of joint matrimonial life for men and women - more than half of those born in the 1980s and 1990s acquire their first experience of living together without registering their relationship. Thus, in Russia, as in all developed countries, the overall level of fertility depends not only on the behavior of partners who have registered their marriage, but also, to a large extent, on the reproductive decisions of those couples who, for whatever reason, do not register their union. At the same time, current Russian family policy apparently sends stimulatory signals only for traditional marriages.

Estimates made on the basis of current registration of births, as well as the Microcensus of 1994 and the National Population Censuses of 2002 and 2010, indicate that if, in the early 2000s, an increase in the intensity of births within wedlock was accompanied by an increase in births out of wedlock, then in the second half of the 2000s the rise in births outside a registered marriage 
practically stopped. There were 0.65 births per woman not in a registered marriage in 1993-1994, 0.74 in 2002-2003 and 0.75 in 2011-2012. This halting of the growth of out-of-wedlock births and the increase of in-wedlock births have led to a decline in recent years in the proportion of children born out of wedlock in the total number of births: in 1980 the proportion was $11 \%$, in $199015 \%$, in $200028 \%$, in $200530 \%$, in $201025 \%$, in $201224 \%$ and in $201323 \%$. It must be noted that the currently increased fertility is observed, first of all, in those developed countries where the number of out-of-wedlock births is large (about one live birth per woman or even more) and their contribution to total fertility is high (close to $50 \%$ or even higher).

Even with the positive developments of recent years, the net reproduction rate of 0.813 observed in 2013 indicates that, taking into account mortality, the current level of fertility provides only an $81 \%$ replacement of the current generation of mothers. Practically, this means that if, over the next two or three decades, the currently observed patterns of period fertility and female mortality do not change, each subsequent generation will be $20 \%$ smaller than the previous one.

In Russia, fertility level among different ethnic groups varies, although the differences are gradually being smoothed out. Fig. 8 shows the number of children born to women aged at the time of the 2010 Census 25-29 years and 30-34 years for the 20 largest ethnic groups accounting for more than $92 \%$ of Russia's population.

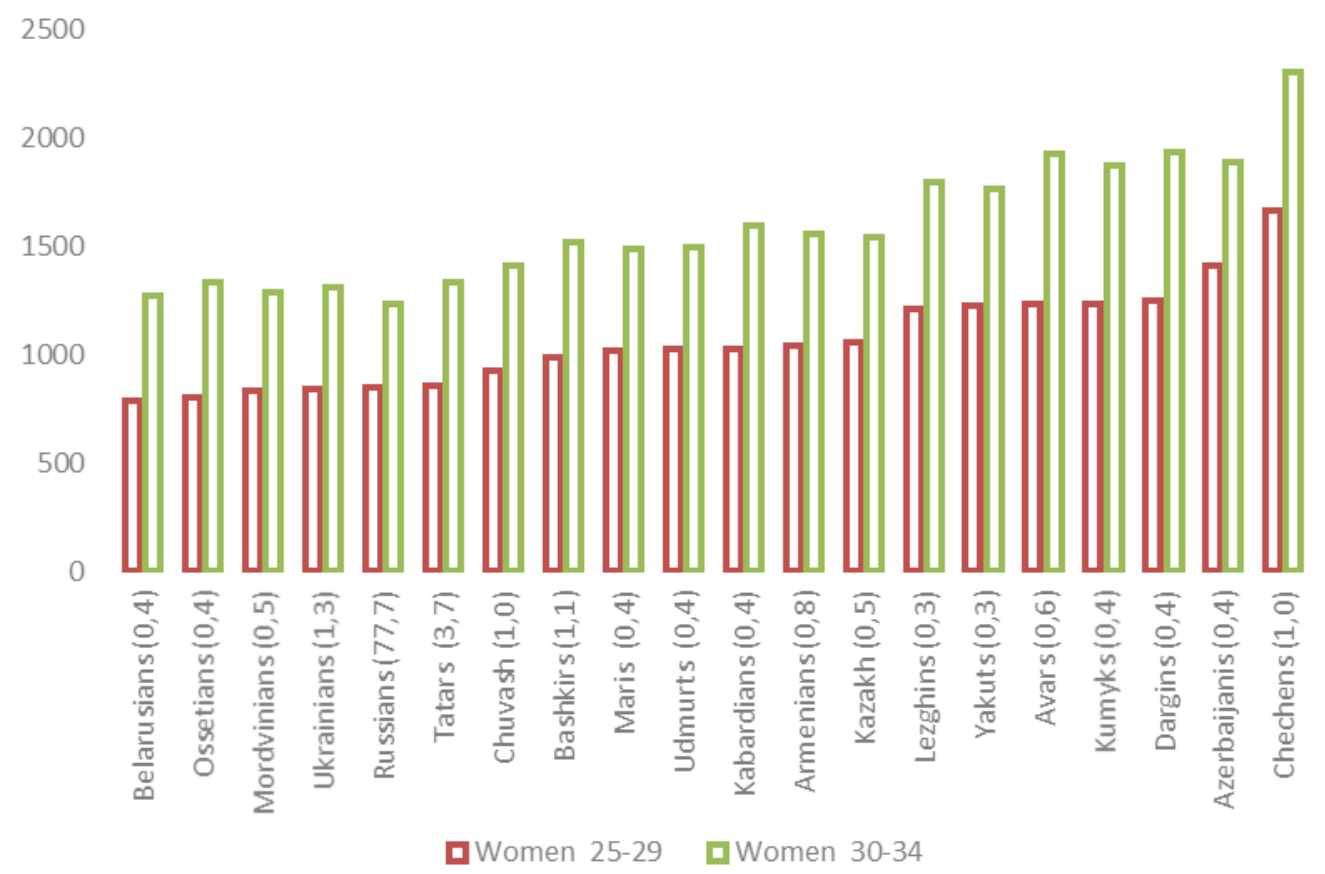

\section{Figure 8. Number of births to 25-29 and 30-34-year-old women of the 20 largest ethnic groups (columns, per 1000 women) and proportion of respective groups in Russia's population (in parentheses, percent)}

Source: Rosstat (2010). 2010 All-Russia Population Census. URL:

http://www.gks.ru/free_doc/new_site/perepis2010/croc/perepis_itogi1612.htm (accessed: 08.08.2014)

Recent positive developments include a steady reduction in the number of abortions in Russia over the last 20 years (Fig. 9), which more and more are being replaced by modern methods of birth control. From 1988 to 2013, both absolute numbers and abortion rates (per 1,000 women 
of reproductive age) declined by 4.5 times. The average annual decline in the abortion rate was $6 \%$, while in the 1990 s this figure decreased faster than in the 2000s. Since 2010, its decline has slowed even more, although the abortion rate is still much higher than in most European countries. In Russia there are 53 abortions per 100 births (2013), as compared with the average of 27 abortions in 53 countries of the WHO European Region (2012) and 22 abortions in the European Union (2012). The abortion rates in Belgium, Germany, the Netherlands and Switzerland are 3.54 times lower than in Russia.

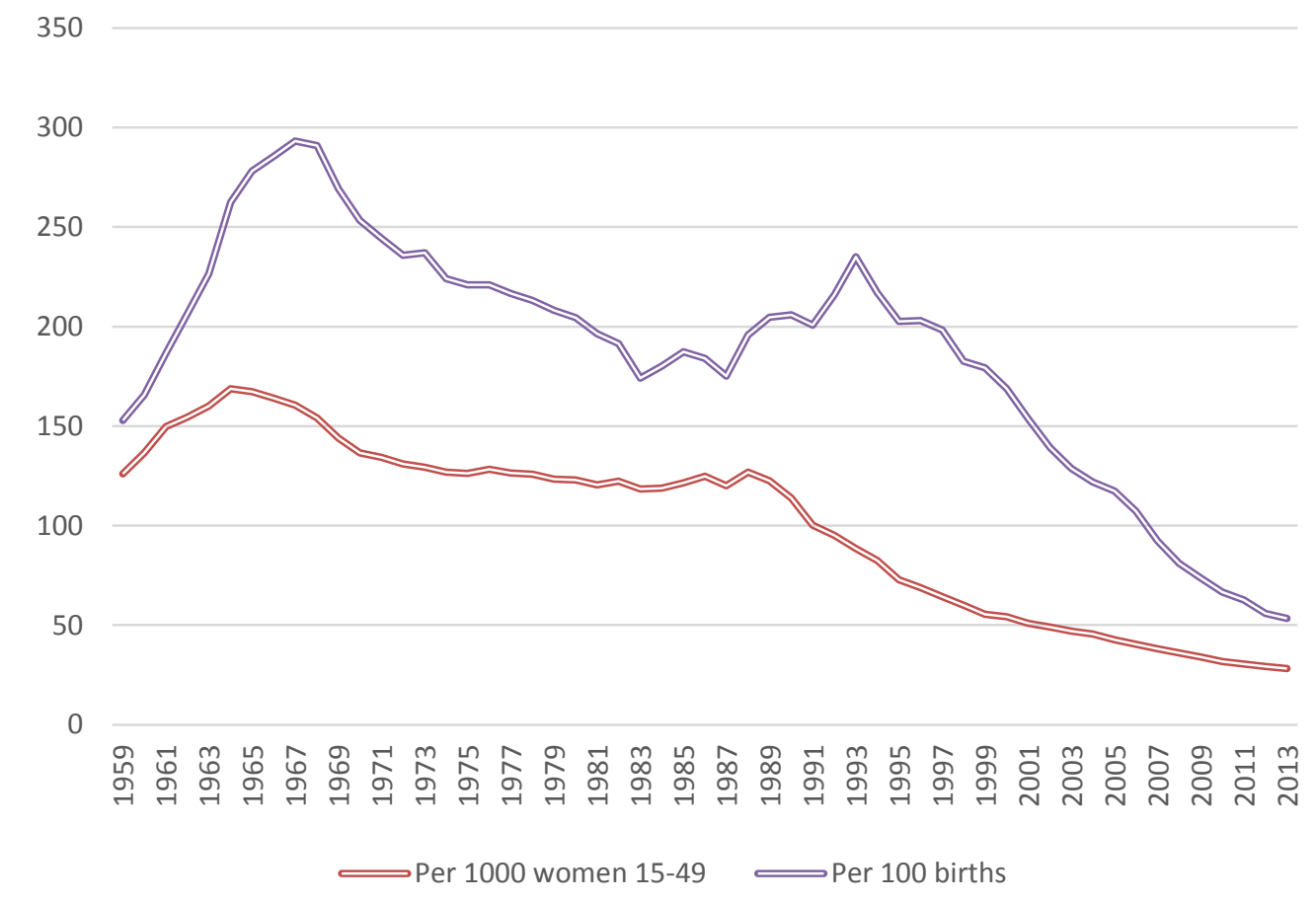

Figure 9. Annual number of abortions per 1,000 women of reproductive age and per 100 births

\section{MORTALITY AND LIFE EXPECTANCY}

Another important positive trend of recent years is the reduction in mortality and the consequent decrease in the absolute number of deaths, which has also contributed to the restoration of the natural increase of population of Russia. That contribution could have been even greater if not for the changes in the age and sex composition of the population of Russia, which in the last 10 years, in terms of the dynamics of deaths, have been unfavorable. If the population, age and sex composition in 2013 were the same as in 2003, the reduction in the number of deaths would have been not the actual 494 thousand, but 748.5 thousand, or 1.5 times bigger.

In the future, the adverse impact of the age composition on the number of deaths, regardless of the dynamics of age-specific mortality rates, will increase. In the 2000s, Russia has experienced an unusual suspension of aging and even a reduction in the number of older people with higher mortality, which has slowed down the increase in the number of deaths. Starting in 2001, those turning 60 belonged to small generations born in 1941 and subsequent years. As a result, the number of elderly people aged 60 and older dropped during 2002-2005 from 27.1 to 24.5 million 
people, or by $9.6 \%$. However, these favorable short-term changes are transient and, in the long term, cannot compensate for structural effects of aging that promotes growth in the number of deaths. Since 2006, the number of elderly has been increasing, reaching 27.2 million people by 2013, and this growth will continue.

A more complete understanding of the dynamics of mortality is given by an analysis of changes in life expectancy which are independent of the age structure (Fig. 10). Life expectancy has been growing continuously since 2004; in 2013, it was higher than in 2003 by 6.61 years for men, 4.46 years for women and 5.93 years for both sexes combined.

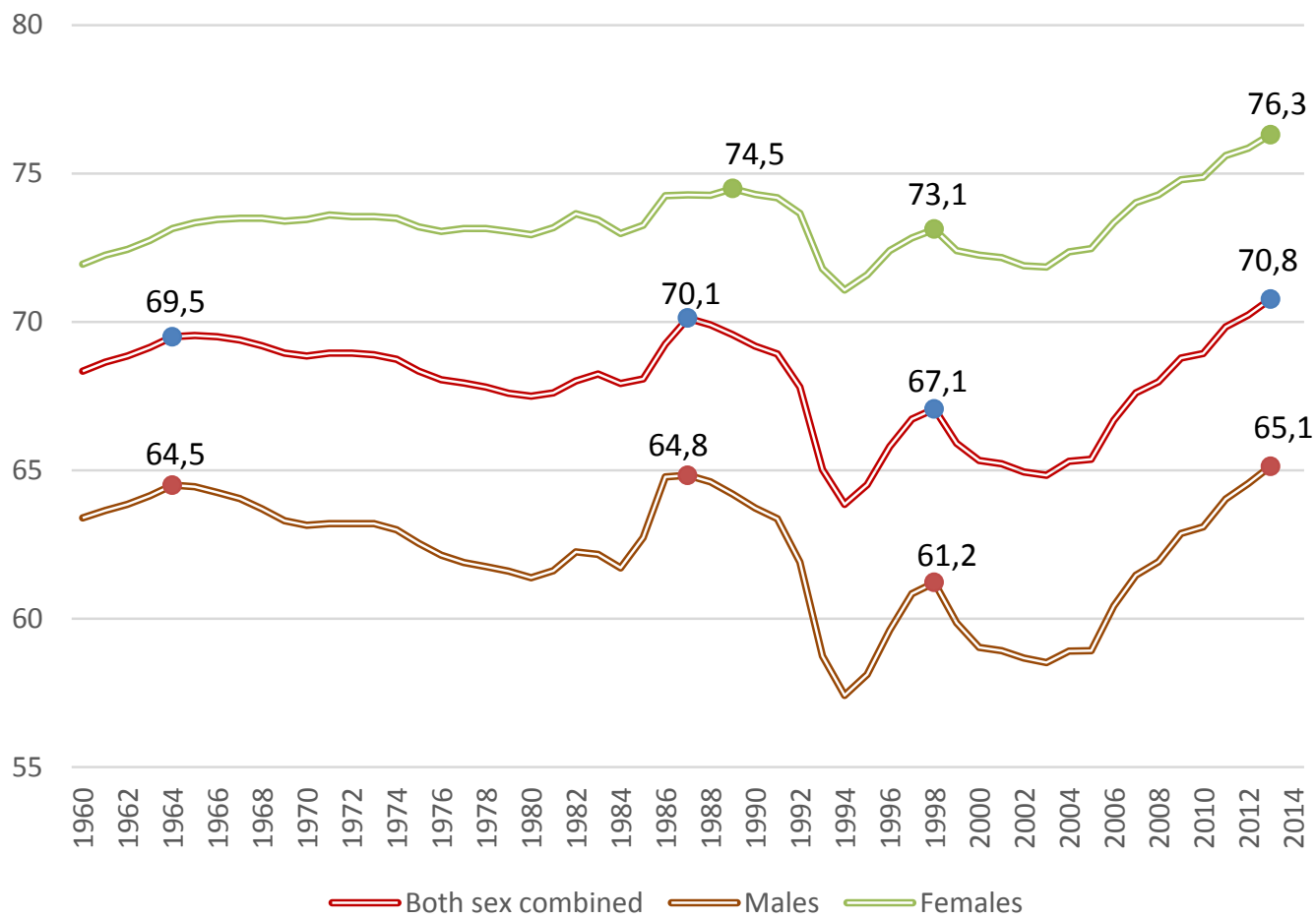

Figure 10. Life expectancy at birth, years

In assessing the achievements in the growth of life expectancy of Russians over the past decade, it should be kept in mind that this indicator has been subject to strong fluctuations over a lengthy period of time. For half a century, Russia has been unable to solve the problem of a sustainable return to its own best achievement, of the mid-1960s. This achievement was repeated and even somewhat surpassed only once, and for only a very short time, in the late 1980s, after which it again fell sharply. The current growth in the life expectancy comes on the heels of a deep fall and has, in essence, a restorative character.

As a result of this growth, the previous high (attained in 1989) was exceeded in 2009 for the first time for women, and in 2012 the previous maximum (reached in 1987) was exceeded for both sexes combined; in 2013, life expectancy of men for the first time exceeded 65 years, surpassing the previous maximum of 1987.

Overall, the growth in life expectancy since 2003 can be characterized as a recovery or reversal, and there is hope that in the next few years it will finally become possible to break away 
from the level that has been reached three times over the past 50 years, but which has never been maintained.

This level in itself is quite low. In terms of life expectancy Russia lags behind all developed countries, and this gap is growing, with respect to some countries exceeding 10 or, for men, even 15 years (Fig. 11).

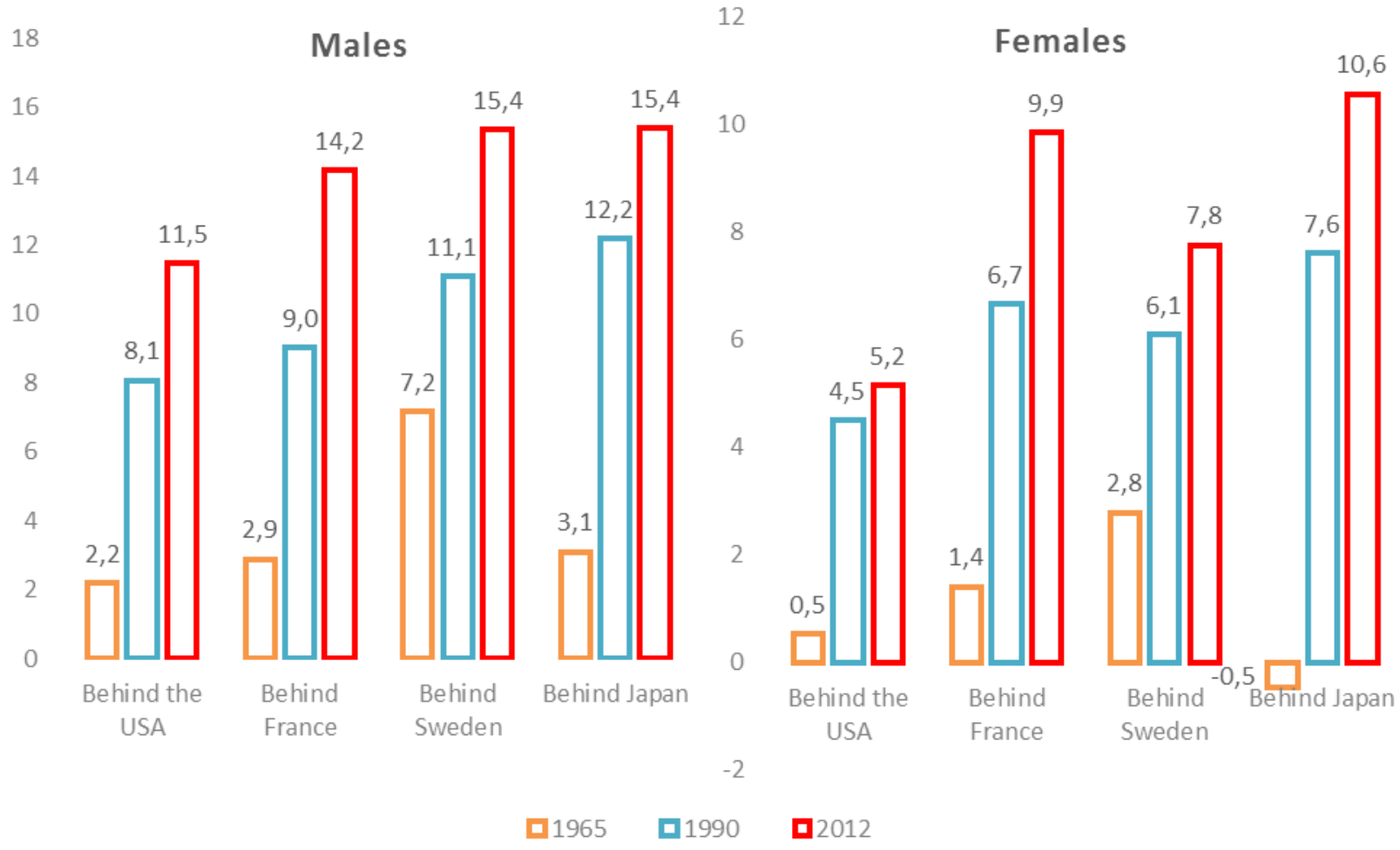

Figure 11. Lag in Russian life expectancy at birth behind the United States, France, Sweden and Japan in 1965, 1990 and 2012 (for the United States and France - 2011), years

During the entire period after 2003, there was a reduction in mortality at all ages and from almost all causes of death. But both of these favorable trends also point to the restorative nature of the favorable changes of the last ten years.

As follows from Fig. 12, for the whole period from 1990 to 2013 the contribution of the decline in mortality to the increase in life expectancy, disaggregated by major age groups, was very close in size to the contribution of the increase in mortality in the same age groups to the decline in life expectancy, particularly among men; in other words, there was to a large degree simply compensation for what had been lost. A clear increase among both men and women could be seen only in the children's group (under age 15) and, to a lesser extent, among the elderly (aged 65 years and older). In the key group of 15-44 years, neither for men nor women was there success even in compensating for the years lost during the periods in which life expectancy had fallen.

A similar picture is given by the disaggregation of the contributions of the increase and decrease of mortality from the major causes of death to changes in life expectancy (Fig. 13). In good years, the decrease of mortality from specific causes positively affected life expectancy, but 
these positive developments only compensated for previous losses of life expectancy due to increased mortality from the same causes. The situation is noticeably better among women, where there was a clear gain from the reduction of mortality from diseases of the circulatory system. But in general, even when there is a gain, it is very small.

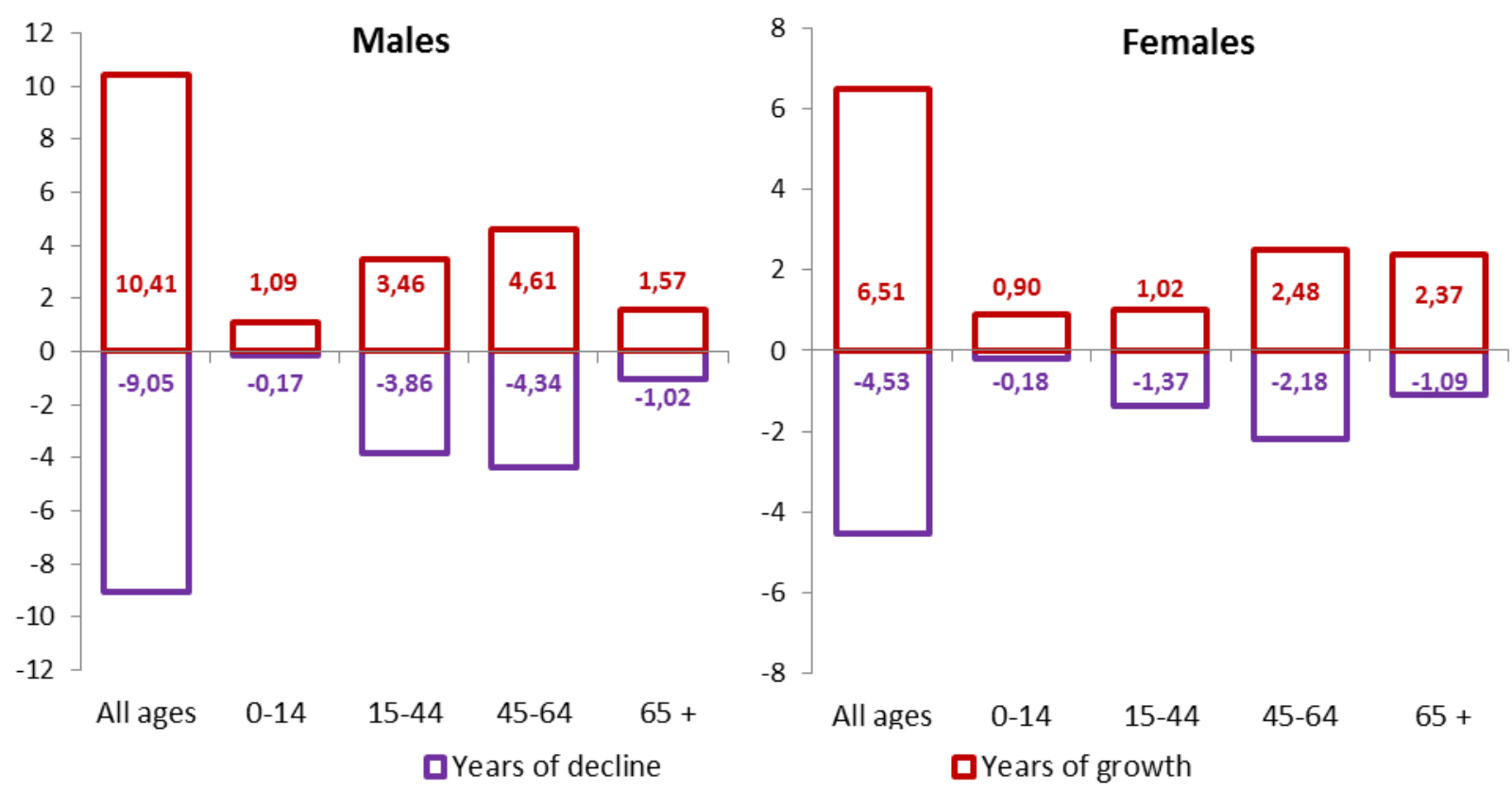

Figure 12. Contribution of major age groups to the fall and rise of life expectancy in 1990-2013, years

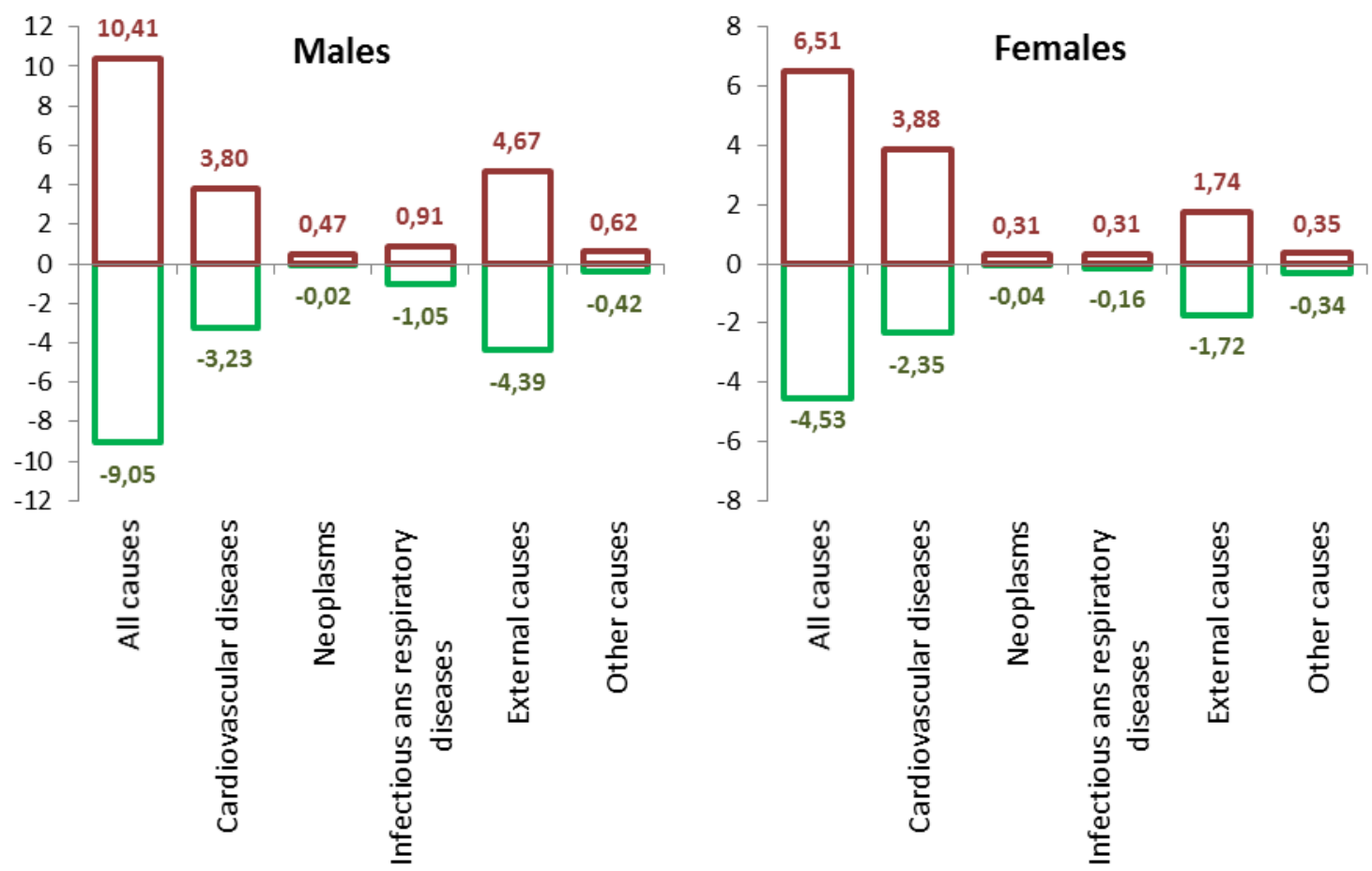

口Years of decline $\square$ Years of growth

Figure 13. Contribution of major causes of death to the fall and the rise in life expectancy in 1990-2013, years 
Thus, the decline in mortality over the last decade has allowed a return to the previously achieved milestones, from which the country can move ahead in reducing the huge accumulated gap between Russia and most developed countries.

\section{POPUlation DiSTRIbUTION AND INTERNAL MigRATION}

Russia's population is very unevenly distributed across the territory of the country (Table. 1). The Asian part of the country, which occupies nearly 3/4 of its territory, is home to only one out of five Russians. In the Central Federal District, which occupies less than $4 \%$ of the territory, lives $27 \%$ of the population. The most densely populated areas are the historical core of Russia and the North Caucasus, but even here the population density is at most half that in the European Union (116 inhabitants per $\mathrm{km}^{2}$ ), roughly corresponding to the density of Northern Europe (55 inhabitants per $\mathrm{km}^{2}$ ). In terms of population density, the European part of the country is comparable to the United States (33 inhabitants per $1 \mathrm{~km}^{2}$ ), while its Asian part is closer to Australia and Canada (about 3 inhabitants per $\mathrm{km}^{2}$ ).

Table 1. Permanent population and territory of the Federal Districts of the Russian Federation at the beginning of 2014

\begin{tabular}{l|c|c|c|c|c}
\hline & \multicolumn{2}{|c|}{ Population } & \multicolumn{2}{c|}{ Territory } & \multirow{2}{*}{$\begin{array}{c}\text { Population density, } \\
\text { inhabitants } / \mathrm{km}^{2}\end{array}$} \\
\cline { 2 - 5 } & Thousands & Percentage & $\begin{array}{c}\text { Thousands } \\
\mathrm{km}^{2}\end{array}$ & Percentage & 8,4 \\
\hline Russian Federation & 143666,9 & 100 & 17098,2 & 100 & 59,7 \\
Federal Districts: & 38819,9 & 27,0 & 650,2 & 3,8 & 8,2 \\
Central & 13800,7 & 9,6 & 1687,0 & 9,9 & 33,2 \\
North-western & 13963,9 & 9,7 & 420,9 & 2,5 & 56,3 \\
Southern & 9590,1 & 6,7 & 170,4 & 1,0 & 28,7 \\
North Caucasian & 29738,8 & 20,7 & 1037,0 & 6,1 & 6,7 \\
Volga & 12234,2 & 8,5 & 1818,5 & 10,6 & 3,7 \\
Ural & 19292,7 & 13,4 & 5145,0 & 30,1 & 1,0 \\
Siberian & 6226,6 & 4,3 & 6169,3 & 36,1 & 26,5 \\
Far Eastern & 114601,2 & 79,8 & 4319,8 & 25,3 & 2,3 \\
European part of Russia & 29065,7 & 20,2 & 12778,5 & 74,7 & \\
Asian part of Russia & \multicolumn{1}{c}{ Source: Rosstat (2014) Popution } \\
\hline
\end{tabular}

Source: Rosstat (2014). Population Size and Migration in the Russian Federation in 2013. Statistical Bulletin.

The uneven distribution of the population of the country is partly due to climatic conditions - about $70 \%$ of the territory of Russia lies in the Far North and comparable regions ill-suited for permanent living. But there is an additional impact of limited demographic resources. The population of Russia, though in itself not small, is still not big enough to populate such a huge territory. Lately, the situation has been worsened by unfavorable trends in inter-regional migration.

Throughout the $20^{\text {th }}$ century, the dominant trend of settlement was a regulated - sometimes using very harsh measures - population shift to the north and the east and, to a lesser degree, to the south. The share of Russians living in the Asian part of the country grew, from $13.3 \%$ in 1926 to $21.8 \%$ in 1989 . In the $1990 \mathrm{~s}$ and $2000 \mathrm{~s}$, a reverse trend has prevailed - a displacement of the population from the northeastern regions of the country towards the southwest. Overall, in the period between the censuses of 1989 and 2010 the populations of the Asian and European parts of Russia decreased by almost $10 \%$ and $0.9 \%$, respectively As a result, the share of the Asian part in the population of Russia fell to $20.3 \%$. 
The general thrust of internal migration flows over the past two decades has been dubbed "westward drift". Its scale reached its maximum in the mid-1990s. According to current registration data, the eastern regions of the country were losing about 150 thousand people annually. As a result, some regions lost a significant proportion of their inhabitants: the population of Chukotka fell by more than half, the population of the Magadan region fell by $40 \%$, and in a number of other regions the losses came to a few dozen percentage points. The departure of the population was stimulated not only by economic reasons; a large role was also played, for example, by the reduction of the army in the east of the country.

The reduction of the westward drift in the 2000s was associated with a decrease in the migration potential of the Far East; Siberia continued to lose population. At the same time, the need for migrants in the largest metropolitan areas of the European part of the country increased, which led to a growing outflow from the Volga region and to a redistribution of the population within the Western part of the country. There remain only few regions that can "hold" the population (with "zero" or positive balance of internal migration flows), even in the European part of the country.

The weakening of the "westward drift" in the 2000s occurred primarily due to the reduction in the exodus from the Far East (Table. 2), but judging by the indicators in the last three years, it is again increasing. Data from the 2002 and 2010 censuses show that the extent of the westward drift is underestimated by current records. The apparent increase in the statistically recorded population outflow from Siberia and the Far East is due to a better recording of inter-regional migration rather than to a real new wave from the east.

Table 2. Western drift in the years 1991-2013, annual average, thousands of persons

\begin{tabular}{|c|c|c|c|c|c|c|}
\hline \multirow[b]{2}{*}{ Period } & \multicolumn{6}{|c|}{ Migratory increase (decrease) of: } \\
\hline & 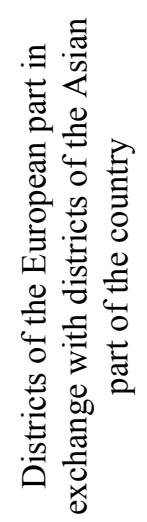 & 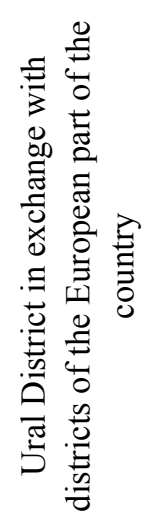 & 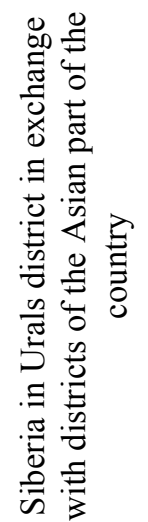 & 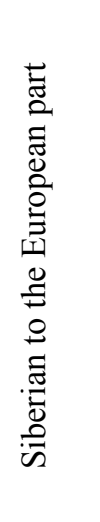 & 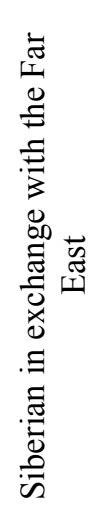 & 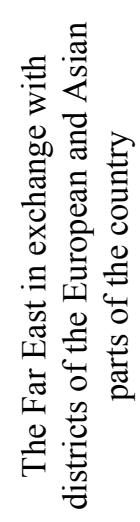 \\
\hline 1991-2000 & 92,9 & $-14,2$ & 6,8 & $-29,5$ & 10,9 & $-67,0$ \\
\hline $2001-2010$ & 56,3 & $-8,6$ & 4,5 & $-28,9$ & 2,1 & $-25,4$ \\
\hline 2011 & 73,6 & $-6,2$ & 8,1 & $-43,2$ & 2,5 & $-32,4$ \\
\hline 2012 & 80,4 & $-5,4$ & 7,1 & $-39,6$ & 3,1 & $-36,0$ \\
\hline 2013 & 107,8 & -21 & 4,6 & $-54,9$ & 2,8 & $-39,3$ \\
\hline
\end{tabular}

A two-fold increase in the redistribution of the population between the Federal Districts 268 thousand people in 2013 versus 134 thousand on average per year for the years 2001-2010 - 
occurred as the result of a more than two-fold growth in the scale of counter-migrations between large parts of the country. In 2010, 74.4 thousand people moved from the European part of the country to the Asian part, whereas in 2013 it was 170.9 thousand - that is, the flow increased by 2.3 times. 139.3 thousand people moved in 2010 from the Asian part to the European part, while in 2013 the flow reached 278.7 thousand. Similarly, the counter-flows between all the federal districts doubled.

As a result, the statistically recorded flow of migrants from the Asian to the European part of Russia, which had shrunk in the 2000s, in 2013 returned to the 1990 level (Fig. 14), but the simultaneous flow in the opposite direction is only $78 \%$ of the level in 1990 . This casts doubt on the possibility of stopping the outflow of population from the regions of Siberia and the Far East, as was expected to happen by the end of the second phase (2021) of the implementation of the Concept of the National Migration Policy in the Russian Federation ${ }^{2}$. Formally, the migration balance of Siberia and the Far East can be reduced to zero, but more likely due to the influx of international migrants compensating for the departure of the population to the west of the country.

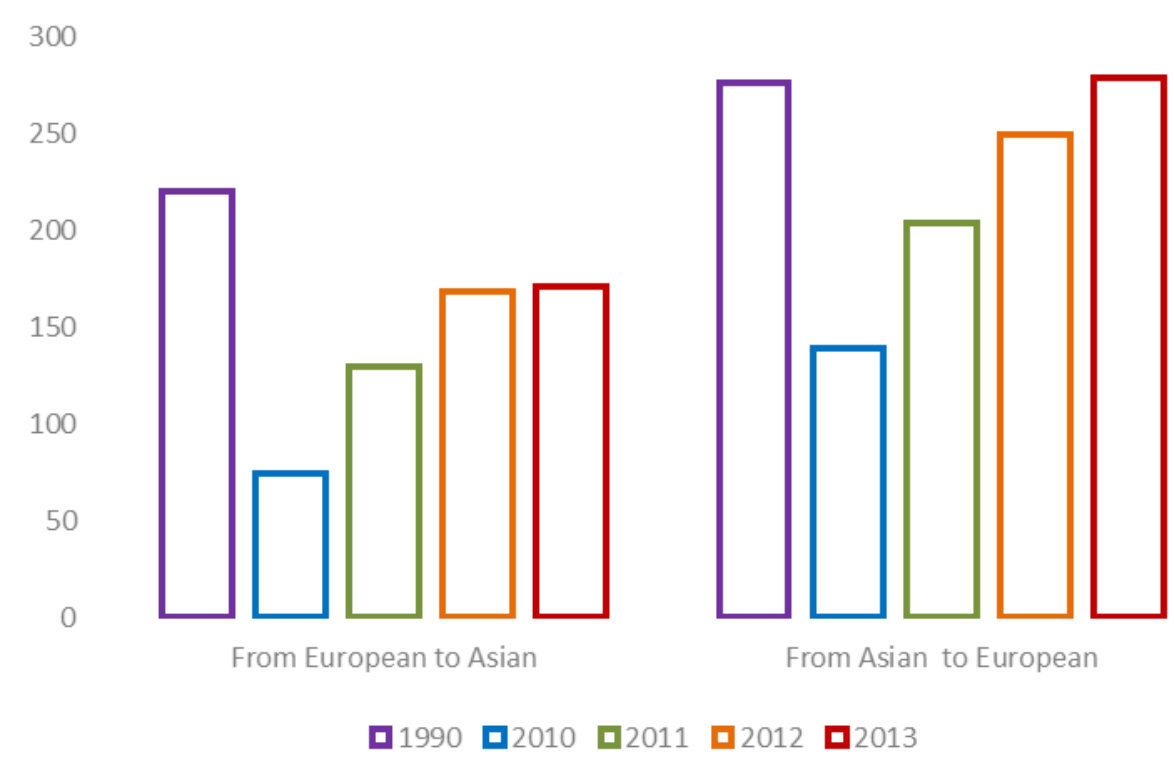

Figure 14. Number of in-migrants to the European and Asian parts of the country, thousands

The main center of attraction for internal migrants in Russia is Moscow and the Moscow Region (the capital region), forming a single labor and housing market. The population growth in this region due to internal migration, according to the census data of 2002 and 2010, comes to nearly 4 million persons since the beginning of the 1990s. If these trends are maintained - a possibility suggested by current trends as well as by plans for developing the territory of Moscow - then within the present decade the inflow of population will reach at least 1.5 million people. The capital region attracts people from all across the country, but most intensively from its European part.

With respect to internal migration, the second center of prime national importance, lagging though far behind the Moscow Region, consists of the city of St. Petersburg and the Leningrad

\footnotetext{
${ }^{2}$ Approved by the President's Decree from 13 June 2012. 
region, where the total increment can be estimated at approximately 700 thousand people over two decades. The "Second Capital" also attracts people from all over Russia, but almost a third of migration increase is provided by the northwestern regions and another $40 \%$ by the eastern regions.

A stable center of attraction of migration is the Krasnodar Region, which has boosted its population since the early 1990 s by about 0.5 million people due to the influx of migrants from other parts of the country - primarily from its Asian part, as well as from the North Caucasus.

Other centers of attraction of migrants are less important (Table. 3). In recent years, the Tyumen and Sverdlovsk regions in particular stand out as centers of attraction.

Table 3. Main centers of attraction of migration in Russia, 1991-2012

\begin{tabular}{l|rrrr}
\hline \multirow{2}{*}{ Centers } & \multicolumn{3}{c}{ Increase due to internal migrations, thousand persons (estimate) } \\
\cline { 2 - 5 } & $1991-2000$ & $2001-2010$ & $1991-2010$ & $2011-2012$ \\
\hline Moscow and Moscow Region & 1860 & 1890 & 3750 & 305 \\
St. Petersburg and Leningrad Region & 200 & 500 & 700 & 101 \\
Krasnodar region & 300 & 200 & 500 & 54 \\
Novosibirsk Region & 25 & 25 & 50 & 19 \\
Belgorod region & 75 & 55 & 130 & 7 \\
Tatarstan & 50 & 35 & 85 & 6 \\
Kaliningrad Region & 30 & 15 & 45 & 5 \\
Nizhny Novgorod Region & 20 & 10 & 30 & 2 \\
Samara Region & 70 & 40 & 110 & 0 \\
Stavropol Region & 165 & 50 & 215 & -3 \\
\hline
\end{tabular}

Source: estimates based on current records of the population and 1989, 2002 and 2010 population censuses.

Due to internal migrations, the population of largest and large cities and their agglomerations is growing, while rural areas and small and medium-sized cities are losing population. As a result, not only the structure of the population is changing in the outflow areas, but the basis for its further reproduction is shrinking. In contrast, large cities and regional urban centers, including the most attractive ones for migrants, are receiving additional boosts from young people coming from the periphery.

Migration involving relocation (change of place of permanent residence), data for which is included in Russian official statistics, is closely linked with temporary migratory moves occurring mainly for labor purposes. Estimates of the magnitude of temporary labor migration vary. According to some estimates, in modern Russia regular migrant labor ('otkhodnichestvo') supports 15-20 million families, and there are areas where up to $80 \%$ of the population engage in such work [Plyusnin 2012]. According to the Employment Survey, ${ }^{3}$ in 2012 the number of people working outside their region attained 2.3 million. If we exclude from consideration daily commuting, the number of temporary migrant workers reached 1,563,000, 19\% of whom returned home once a week, 39\% 1-2 times a month, and 42\% less than 1 time per month. A similar number of migrants working outside their regions of permanent residence is shown by the results of the 2010 census. According to this (conservative) estimate, 1.4\% of the Russian population aged 15-72 years old, or $2.2 \%$ of the employed population, has been involved in labor migration.

\footnotetext{
${ }^{3}$ In accordance with the requirements of the International Labour Organization, Rosstat conducts quarterly household surveys.
} 
Unlike long-term migration, whose flows are balanced in terms of gender, temporary labor migration mostly involves men. According to the Employment Survey, among labor migrants in Russia $83 \%$ are men and $17 \%$ are women. The maximum proportion of migrant workers in the total employed population is in the 20-24 and 25-29 age groups, where it is $5.1 \%$ and $4.5 \%$, respectively. The predominance of men in the flows of migrant workers is particularly pronounced at the mean working ages, when women bear the main burden of housework and childrearing. Among migrant workers there are more people aged 30-50 than among those who change their place of permanent residence.

Among migrants, the proportion of people with higher education is smaller than in the general population, while the proportion of those with a primary and general secondary education is higher. Forty percent of migrant workers are employed in construction, a significant proportion in mining, and there are lots of guards. Migrant women are particularly noticeable in retail trade, hotel and restaurant services, as well as in construction. At the same time, migrant workers are few in such industries as agriculture and manufacturing, government, education and healthcare. Russian migrant workers, in comparison with other Russian workers, are less often found in management positions and in positions not requiring qualifications such as "cleaners". Apparently, this last niche is occupied by foreign migrants, because of, among other things, low wages.

\section{EXTERNAL MIGRATION}

Despite the importance of today's internal migrations in Russia, they have not for a long time played the key role they had in the middle of the twentieth century, when the country was experiencing rapid urbanization and developing new regions, giving rise to new points of growth and attraction for migrants. Tens of millions of people went on the move. In contrast, external migration, if meant as including the exchange of populations between Russia and the former Soviet republics, after the collapse of the Soviet Union acquired a meaning for Russia which it had never had before.

International migration is a multidimensional phenomenon with serious economic, social and political importance, but the analysis of these aspects falls outside the scope of this report, which is devoted to the evolution of the demographic situation in the country and views migration primarily as an important means of replenishing the demographic resources of Russia. This is a new role of international migration for our country, which came to the fore in the last two decades, during which the influx of migrants has played an important stabilizing role in terms of the dynamics of Russia's population.

This role of migration is likely to continue in the foreseeable future. For demographic reasons, Russia will hardly be able to refuse to accept migrants. Besides, this will be impossible also for economic considerations tied, in particular, to the features of the population age structure discussed above. 


\subsection{IMMIGRATION}

Migratory movement consists of two counter-flows: immigration and emigration. Currently, immigration gets the most attention in Russia. We have already mentioned its important contribution to the mitigation of the consequences of natural population decline. At the same time, when evaluating the present and future of external migration it is necessary to take into account the specificity of migrations of the last two decades which are in many respects unique.

Above all, the uneven distribution of net migration by stages in the period under consideration should be noted. Of the 8.4 million people making up the net positive migration during 1990-2013, 3.6 million (43\%) came from the migration spike of 1993-1998. In the following years net migration fluctuated, but was generally substantially smaller.

In addition, the immigration of the 1990s, and to a large extent of the 2000s, consisted essentially of "return migrants" or, in other words, of repatriation of "compatriots". This characterization can be confirmed by the ethnic composition of migrants, which has been recorded until 2007. Among the migrants who moved to Russia in the 1990s and 2000s, most were natives of Russia or their descendants. This began to change noticeably only in the second half of the 2000s. If in 1997 they accounted for $70 \%$ (including $62 \%$ of ethnic Russians), in 2007 the figure was only $37 \%(30 \%)$.

During the first post-Soviet decade, foreign populations of ethnic Russias provided the large potential for in-migration and balanced the natural population decline. Consequently, this potential shrank abruptly. In the future, maintaining such migration inflow will be much harder, since new generations of in-migrants will, in the process of integration, have to overcome a much greater cultural gap than in the past.

Yet the situation is somewhat mitigated by the fact that, despite the changing ethnic composition of migrants, the vast majority of them still come from former republics of the USSR (Table 4).

Some migration from the CIS countries was implemented as part of a government program to promote resettlement of compatriots. Altogether, in 201335 thousand people came to the Russian Federation within the framework of this program (in 2012 - 55 thousand.). The total number of participants in the program since its inception in 2007 increased to almost 150 thousand, which is considerably lower than expected.

All of the above applies to permanent (long-term) migration, which is factored in the size of the resident population. But Russia's international migration exchange consists of two components: permanent migration and temporary displacements presuming the return of migrants to their country of origin. Temporary migration is not included in the balance sheet of movements of Russia's permanent population. However, temporary labor migration has a significant impact on socio-economic development, and many problems that emerged in Russia in connection with the influx of migrants are due to this particular part of the migratory flow.

There are serious unresolved problems of keeping records of both permanent and temporary migrants, and of comparability of time series arising from changes in the criteria of attribution to different migrant categories, etc. Therefore, official estimates of Rosstat, which are 
generally used in this report, are not free of drawbacks. This especially concerns, as will be shown later, estimates of emigration to the countries outside the former Soviet Union (Germany, Israel, the US and other countries.). Yet these estimates nonetheless give an idea of the main directions and composition of migration flows, and of some important characteristics of migrants.

A summary indicator of migratory movements is provided by net migration, which is the difference between the flows of immigrants and emigrants. In the calculation of net migration, it is assumed that the fluctuations in the statistics for each of the two streams, caused by changes in the rules of recording migrants, are eliminated.

Table 4. International migration in Russia in 2011-2013, persons

\begin{tabular}{|c|c|c|c|c|c|c|c|c|c|}
\hline & \multicolumn{3}{|c|}{2011} & \multicolumn{3}{|c|}{2012} & \multicolumn{3}{|c|}{2013} \\
\hline & 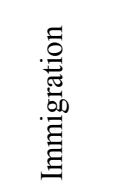 & 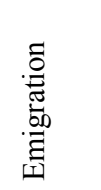 & 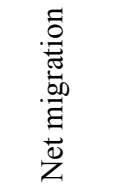 & 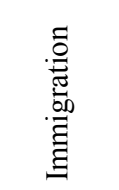 & 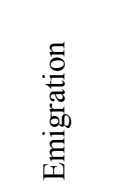 & 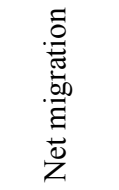 & 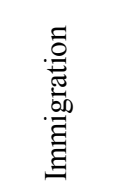 & 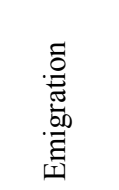 & 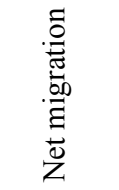 \\
\hline Total Russia & 356535 & 36774 & 319761 & 417681 & 122751 & 294930 & 482241 & 186382 & 295859 \\
\hline CIS countries & 310549 & 22568 & 287981 & 363955 & 95572 & 268383 & 422738 & 147853 & 274885 \\
\hline Azerbaijan & 22316 & 1255 & 21061 & 22287 & 4185 & 18102 & 23453 & 6207 & 17246 \\
\hline Armenia & 32747 & 1000 & 31747 & 36978 & 4980 & 31998 & 42361 & 10182 & 32179 \\
\hline Belarus & 10182 & 2622 & 7560 & 16564 & 6315 & 10249 & 15748 & 12031 & 3717 \\
\hline Kazakhstan & 36474 & 6176 & 30298 & 45506 & 8843 & 36663 & 51958 & 11802 & 40156 \\
\hline Kyrgyzstan & 41562 & 976 & 40586 & 34597 & 10489 & 24108 & 30388 & 10576 & 19812 \\
\hline Moldova & 19578 & 771 & 18807 & 23594 & 4949 & 18645 & 28666 & 8038 & 20628 \\
\hline Tajikistan & 35087 & 1070 & 34017 & 41674 & 10281 & 31393 & 51011 & 17362 & 33649 \\
\hline Turkmenistan & 4524 & 191 & 4333 & 5442 & 1555 & 3887 & 5986 & 2165 & 3821 \\
\hline Uzbekistan & 64493 & 2207 & 62286 & 87902 & 31559 & 56343 & 118130 & 50864 & 67266 \\
\hline Ukraine & 43586 & 6300 & 37286 & 49411 & 12416 & 36995 & 55037 & 18626 & 36411 \\
\hline $\begin{array}{l}\text { Other countries } \\
\text { Including: }\end{array}$ & 45986 & 14206 & 31780 & 53726 & 27179 & 26547 & 59503 & 38529 & 20974 \\
\hline Abkhazia & 2429 & 175 & 2254 & 2487 & 951 & 1536 & 3001 & 992 & 2009 \\
\hline Vietnam & 3294 & 95 & 3199 & 3653 & 1258 & 2395 & 3852 & 2355 & 1497 \\
\hline Germany & 4520 & 3815 & 705 & 4239 & 3781 & 458 & 4166 & 3979 & 187 \\
\hline Georgia & 7325 & 416 & 6909 & 7728 & 801 & 6927 & 7665 & 1553 & 6112 \\
\hline Israel & 1240 & 977 & 263 & 1091 & 1104 & -13 & 1132 & 1090 & 42 \\
\hline India & 1390 & 43 & 1347 & 1068 & 931 & 137 & 1451 & 1146 & 305 \\
\hline China & 7063 & 507 & 6556 & 8547 & 4358 & 4189 & 8149 & 7527 & 622 \\
\hline North Korea & 1948 & 152 & 1796 & 4168 & 1603 & 2565 & 5023 & 3891 & 1132 \\
\hline Latvia & 1350 & 181 & 1169 & 1427 & 431 & 996 & 1484 & 556 & 928 \\
\hline USA & 947 & 1422 & -475 & 1122 & 1561 & -439 & 954 & 1485 & -531 \\
\hline Turkey & 1832 & 252 & 1580 & 2252 & 1037 & 1215 & 2755 & 1494 & 1261 \\
\hline Estonia & 1588 & 266 & 1322 & 1537 & 613 & 924 & 1475 & 726 & 749 \\
\hline $\begin{array}{l}\text { The rest of the } \\
\text { world }\end{array}$ & 11060 & 5905 & 5155 & 14407 & 8750 & 5657 & 18396 & 11735 & 6661 \\
\hline
\end{tabular}

Source: Rosstat (2014). Population Size and Migration in the Russian Federation in 2013. Statistical Bulletin.

However, the problem of the quality of record-keeping when shifting to an index of net migration has not been fully resolved. This can be seen from the significant discrepancies between the estimates of net migration from current registration and population censuses.. Net migration for the period between the censuses of 1989 and 2002, calculated on the basis of census data, exceeded net migration based on data from current records by more than 1.5 million people. For the period of 2003-2010, the total stood at 1.2 million people.

Fig. 15 shows the number of those leaving Russia and arriving in Russia for a long period of time, according to an official assessment by Rosstat, taking into account post-census corrections. 


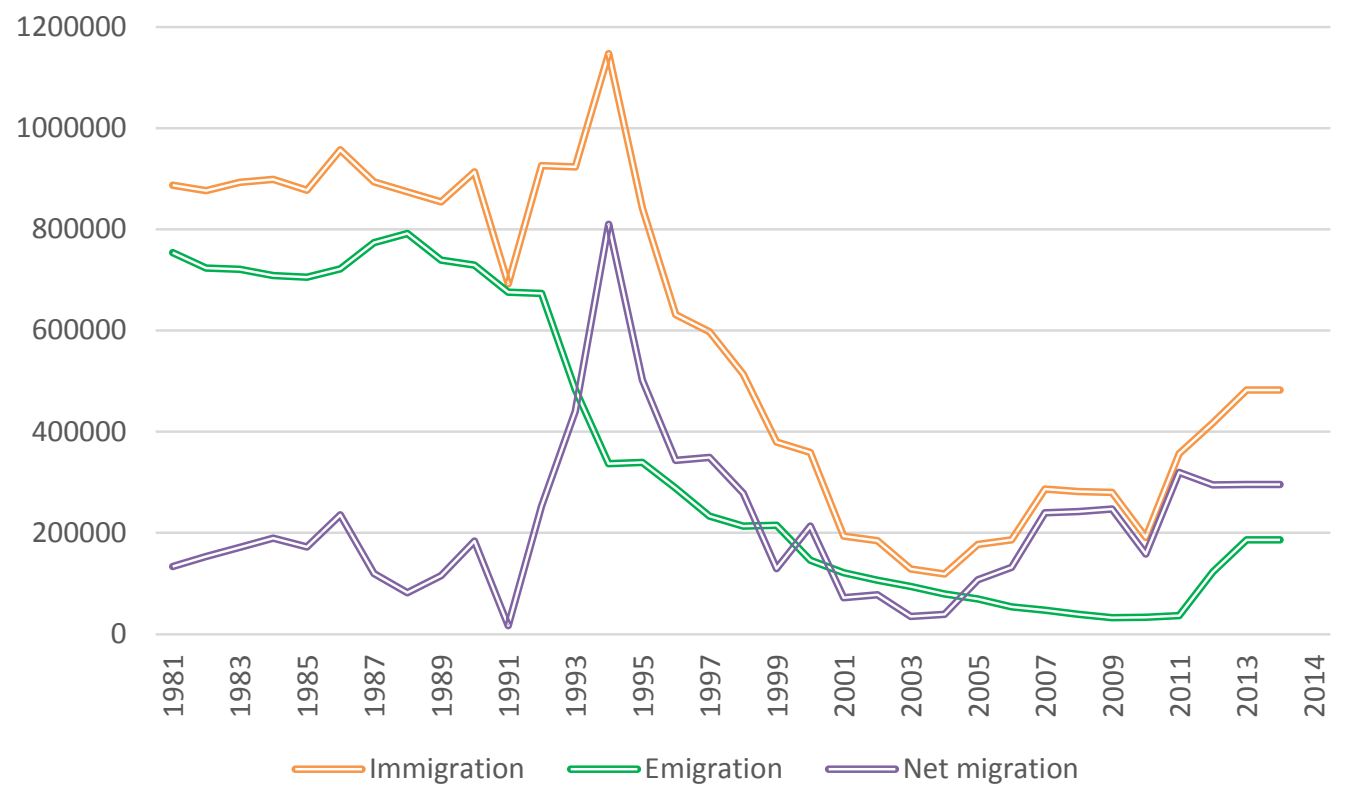

Figure 15. Immigration, emigration and net migration, Russia 1980-2014, thousands

As noted, former Soviet republics remain the main source of population inflow into Russia. In the 1990s, the proportion of immigrants from the former Soviet space in the overall flow of immigrants was, as a rule, in the interval of 96-97\%. Now it has diminished somewhat, but has never dropped below 90\%. Fig. 16 presents the data on annual arrivals in Russia according to year and, beginning in 1997, from largest source countries.

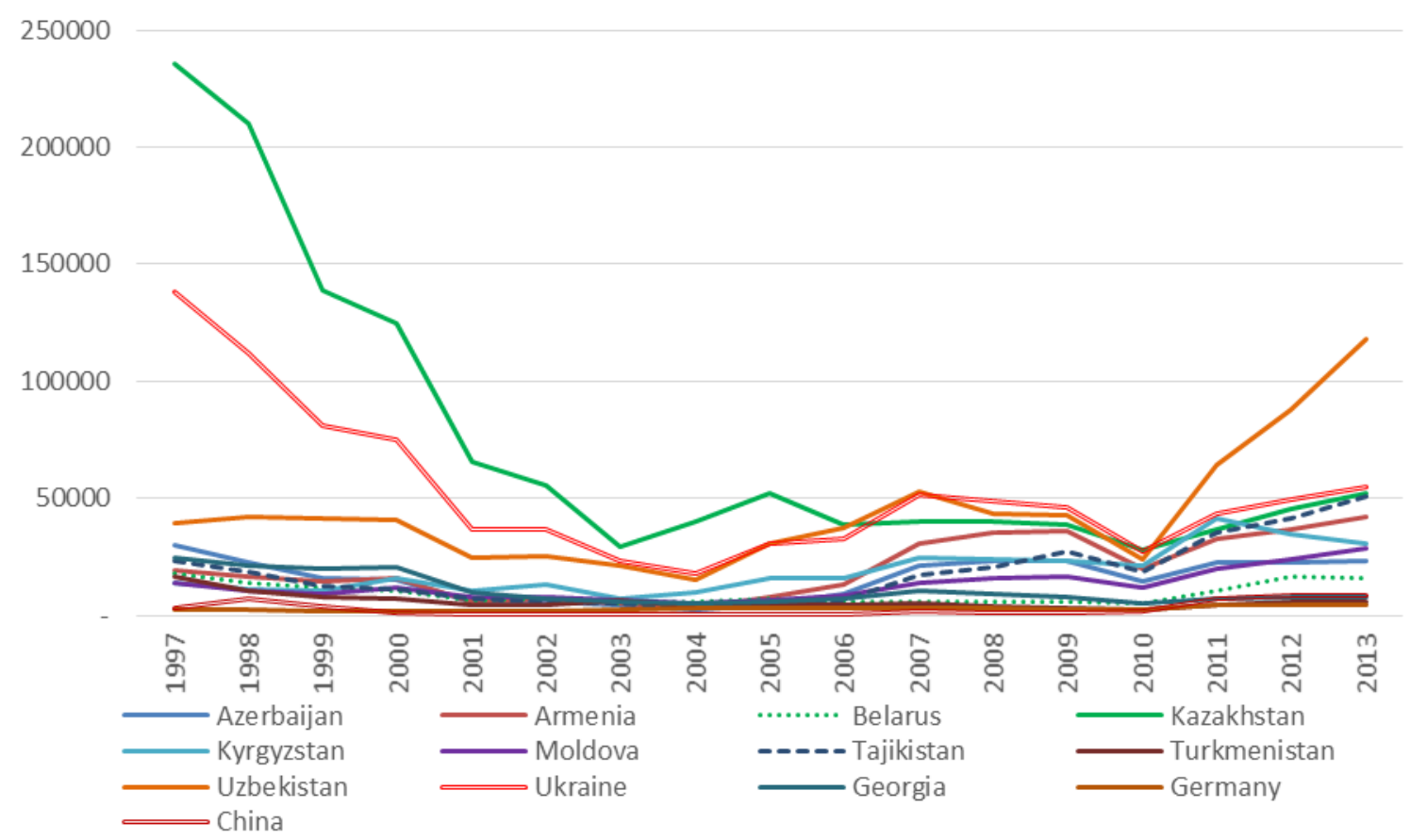

Figure 16. Immigration from countries with which Russia has the most intense migration exchange, 1997-2013, thousands

Temporary migration to Russia may have various causes (e.g. education, medical treatment, tourism, etc.), but its main streams are work-related. 
In 2013, the Russian migration authorities issued about 3 million work permits for nationals from 141 countries (Table 5). But even greater was the number of foreigners working without such permission, i.e. illegally. According to some experts and executives of the Federal Migration Service, there were 3-5 million such people.

Table 5. Main indicators of recorded international labor migration to Russia in 2010-2013, thousands

\begin{tabular}{l|c|r|r|r}
\hline Category & \multicolumn{1}{|c|}{2010} & 2011 & 2012 & \multicolumn{1}{c}{2013} \\
\hline Annual quota & 1944 & 1746 & 1746 & \multicolumn{1}{c}{1746} \\
Total work permits issued & 863.0 & 1219.8 & 1403.6 & 1368.3 \\
Including: & & & & \\
$\quad$ Foreigners requiring an entry visa & 203.7 & 204.7 & 220.3 & 204.7 \\
$\quad$ Foreigners not requiring an entry visa & 659.4 & 1015.1 & 1183.4 & 1163.5 \\
$\quad$ Skilled specialists & - & - & 44.1 & 129.4 \\
$\quad$ Highly skilled specialists & 3.1 & 11.3 & 11.8 & 26.3 \\
Work licenses issued & 156.9 & 862.4 & 1283.4 & 1537.8 \\
Total number of documents giving the right to work & 1330.0 & 2093.5 & 2698.8 & 2932.4 \\
\hline$\quad$ Source: Russian Federal Migration Service (FMS). & & & &
\end{tabular}

Most migrant workers are citizens of CIS countries with visa-free entry into Russia. Their share among those receiving ordinary work permits in 2013 increased to $85 \%$ (in $2007-72 \%$ ). The share of work permits received by citizens from visa-free countries came to about $93 \%$, including licenses to seek work in private households. Citizens of 12 countries, listed in Table 6 , accounted for nearly $97 \%$ of the total in-flow of migrants with work permits. The undisputed leader is Uzbekistan, whose share in 2013 accounted for about 44\% of all work permits issued. Since 2010 , the number of migrant workers from that country has increased three-fold. At the same time, the number of migrants from China, Vietnam, Turkey and Azerbaijan since 2008 decreased by a factor of 2 or more.

Table 6. Number of foreign nationals who received ordinary work permits in Russia, 2008-2013, thousands

\begin{tabular}{l|r|r|r|r|r|r}
\hline Country & \multicolumn{1}{c}{2008} & \multicolumn{1}{c}{2009} & \multicolumn{1}{c}{2010} & \multicolumn{1}{c}{2011} & \multicolumn{1}{l}{2012} & 2013 \\
\hline Total & 1353.9 & 1060.2 & 864.2 & 1220.0 & 1403.6 & 1368.3 \\
$\quad$ including: & & & & & & \\
Uzbekistan & 390.3 & 320.7 & 289.7 & 472.3 & 588.6 & 600.8 \\
Tajikistan & 213.0 & 171.2 & 134.6 & 199.6 & 218.1 & 197.0 \\
Ukraine & 117.8 & 101.6 & 86.8 & 127.8 & 151.2 & 152.0 \\
Kyrgyzstan & 105.5 & 71.8 & 58.5 & 82.7 & 91.5 & 95.1 \\
China & 168.8 & 128.8 & 117.8 & 93.2 & 97.0 & 87.5 \\
Moldova & 60.5 & 48.1 & 34.9 & 54.6 & 60.0 & 57.3 \\
Armenia & 51.0 & 37.3 & 30.7 & 45.9 & 46.1 & 40.6 \\
Turkey & 67.1 & 30.8 & 25.1 & 25.5 & 36.6 & 36.1 \\
North Korea & 17.7 & 18.6 & 19.8 & 21.6 & 26.3 & 29.9 \\
Azerbaijan & 38.8 & 28.0 & 19.1 & 26.46 & 26.54 & 19.7 \\
Vietnam & 48.7 & 44.2 & 17.8 & 14.7 & 14.8 & 12.1 \\
Serbia & & & 6.5 & 7.5 & 10.2 & 12.1 \\
Other & 74.7 & 59.1 & 22.9 & 48.14 & 36.66 & 28.1 \\
\hline
\end{tabular}

Source: Russian Federal Migration Service (FMS).

In recent years, the proportion of men and persons of working age, which was probably due to the general change in the character of migration. Instead of the repatriation of the 1990s, with its strong family component, comes the economic migration of young workers. The 
proportion of working-age persons among migrants is almost a quarter higher than in the population of Russia (tab. 7).

Table 7. The age and sex composition of immigrants in Russia (as \% of the total number of migrants)

\begin{tabular}{l|r|r|r|r|r}
\hline Age & 1994 & 2002 & 2010 & 2013 & Population of Russia. 2013 \\
\hline Total & 100.0 & 100.0 & 100.0 & 100.0 & 100.0 \\
Under working-age & 23.4 & 16.0 & 10.5 & 7.4 & 16.8 \\
Working-age & 66.1 & 65.6 & 79.6 & 84.3 & 60.1 \\
Over working-age & 10.5 & 18.4 & 9.9 & 8.3 & 23.1 \\
Men total & $\ldots$ & 46.9 & 55.1 & 63.7 & 46.3 \\
Under working-age & $\ldots$ & 8.3 & 5.5 & 3.9 & 8.6 \\
Working-age & $\ldots$ & 33.1 & 46.9 & 57.4 & 31.1 \\
Over working-age & $\ldots$ & 5.5 & 2.7 & 2.4 & 6.6 \\
Women total & $\ldots$ & 53.1 & 44.9 & 36.3 & 53.7 \\
Under working-age & $\ldots$ & 7.8 & 5.0 & 3.5 & 8.2 \\
Working-age & $\ldots$ & 32.4 & 32.6 & 26.9 & 29.0 \\
Over working-age & $\ldots$ & 12.9 & 7.2 & 5.9 & 16.5 \\
\hline
\end{tabular}

Source: Rosstat (2014). Population Size and Migration in the Russian Federation in 2013. Statistical Bulletin.

Under the influence of the same factors, the educational composition of migrants is also changing. Compared with the beginning of the 2000 s, the proportion of people with higher and secondary professional education decreased, but the proportion of persons with general secondary and basic vocational education increased. If in the 1990s and early 2000s the level of education of migrants was, on average, higher than among the population of Russia, recently the situation has changed, and the level of education of migrants is lower than of Russians.

\subsection{EMIGRATION}

A new phenomenon of the post-Soviet decades has been large-scale emigration from Russia, mainly to countries beyond the CIS. Unfortunately, the quality of record-keeping for emigration in Russia is even worse than for immigration. Russian emigration statistics are imperfect, Russian data on emigrants differ significantly from estimates obtained on the basis of foreign sources, which testifies to a considerable underestimation of the scale of emigration by Russian statistics. Thus, in 2011-2012 the total outflow from Russia according to national data of 11 countries was 9 times higher than that according to Russian statistics (Table 8). In addition, Russian data do not fully reflect the geography of modern emigration. In particular, they do not show the noticeable increase in such centers of attraction for Russians as Spain, Italy, Austria, Switzerland, France, the United Kingdom and the Czech Republic.

In addition to permanent emigration, there is also temporary labor migration of Russians to foreign countries. According to Federal Migration Service of Russia (FMS) data, in 201265 thousand Russian citizens found jobs abroad. However, these data are likely incomplete. Most Russian citizens employed abroad find work on their own, without the help of organizations reporting to the FMS, and are far from consistently included in its records. 
Table 8. Emigration from Russia according to Russian and foreign sources, 2011-2012, thousands

\begin{tabular}{l|c|c|c}
\hline Countries & $\begin{array}{c}\text { Number of emigrants } \\
\text { according to Rosstat }\end{array}$ & $\begin{array}{c}\text { Immigration from Russia } \\
\text { according to foreign data }\end{array}$ & $\begin{array}{c}\text { Ratio: Col. 3/ } \\
\text { Col. 2 }\end{array}$ \\
\hline Austria & 0.2 & 8.4 & 42 \\
Canada & 1.0 & 3.8 & 3.8 \\
Denmark, Norway, Sweden & 0.7 & 10.1 & 14.4 \\
Finland & 1.1 & 13.4 & 12.2 \\
Germany & 7.6 & 40.4 & 5.3 \\
Israel & 2.1 & 7 & 3.3 \\
Italy & 0.7 & 11.9 & 17 \\
Netherlands & 0.1 & 4.7 & 47 \\
Spain & 0.8 & 31.4 & 39.3 \\
Switzerland & 0.2 & 6.7 & 33.5 \\
United States of America & 3.0 & 20.3 & 6.8 \\
Total & 17.5 & 158.1 & 9 \\
\hline
\end{tabular}

Source: Federal State Statistics Service (Rosstat); National statistical offices.

In general, despite a number of positive trends in recent years, the demographic situation in Russia remains acute and contains a number of potential risks. Although some of the challenges facing the country in this regard can, in principle, be met by further improvement of demographic indicators - particularly mortality and life expectancy - by more flexible immigration policy, the dynamics of population size and age composition in the next few decades will hardy be favorable. This should be taken into account when formulating the objectives of economic and social policy in the coming years.

\section{REFERENCES}

Rosstat (2014). Chislennost' i migratsiya naseleniya Rossiyskoy Federatsii v 2013 godu [Population size and migration in the Russian Federation in 2013]. Statisticheskiy byulleten' [Statistical Bulletin]. Moskva: 3-9.

Plyusnin Y. [Плюснин Ю.] (2012). Otkhodnichestvo v sovremennoy RossiiSeasonal work

[Seasonal work in modern Russia] // Otechestvennye zapiski [Annals of the Fatherland]. 5. 